\title{
Do the burst of financial crisis and European Union membership impact Earnings Management. Evidence from emerging Eastern European countries.
}

\author{
Susana Callao, José I. Jarne, David Wroblewski**
}

\begin{abstract}
The paper studies earnings management in developing European countries. We investigated if membership in the European Union and the recent global financial crisis affected the decisions of managers in Eastern European countries to engage in earnings management.

By analyzing a sample of 4,627 firms from four developing Eastern European countries (the Czech Republic, Poland, Hungary, and Slovakia) over the period of 2002-2009, our findings suggest there was a decrease in earnings management over the period leading up to the accession of these countries to the European Union. Additionally, we found that there was an increase in earnings management after the burst of the financial crisis.

The results contribute to the debate in the accounting literature regarding the variations in earnings management related to the changes in environmental factors influencing companies. These results have several implications for standard setters and regulators; in particular, companies' incentives are strongly influenced by the general conditions and circumstance of their home countries. Additionally, the study explores the still unexplored developing markets of Eastern European countries.
\end{abstract}

Keywords: Earnings management, discretionary accruals, emerging countries, Eastern European countries

JEL Codes: M41, O11, P52

\section{Introduction}

Earnings management has been analyzed from different perspectives in recent decades. Past empirical studies have considered different aspects of earnings management such as its definition, the methodology to detect and measure earnings management, and managerial incentives or environmental circumstances that may stimulate or limit earnings management. No single definition of the concept of earnings management exists, and multiple measures have been used to estimate the degree of earnings management in previous empirical studies.

* Received: 24.9.18, accepted: 1.3.20, 3 revisions.

** Susana Callao, Dr, Lecturer in Accounting, University of Zaragoza, Faculty of Economy and Business, Email: scallao@unizar.es Main research interests: earnings management, quality of the accounting information, financial analysis, international financial information.

José I. Jarne, Dr, Lecturer in Accounting, University of Zaragoza, Faculty of Economy and Business, Email: jijarne@unizar.es Main research interests: earnings management, quality of the accounting information, financial analysis, international financial information.

David Wroblewski, Dr, Associate Professor, University of Zaragoza, Email: david.wroblew ski@cretateologia.es Main research interests: earnings management, emerging countries, quality of the accounting information, financial analysis.

JEEMS, 25 (4) 2020, $608-647$

DOI: $10.5771 / 0949-6181-2020-4-608$ 
This article addresses how environmental factors may affect managers' decisions to manage earnings. In particular, the motivation for this study is to determine how companies from emerging Eastern European countries respond to their external environment, and we consider two important events (the entry of these countries into the European Union and the global financial crisis) and their effects on managers' decisions regarding earnings management.

The 2008 global financial crisis is considered by many economists to have been the worst financial crisis since the Great Depression of the $1930 \mathrm{~s}$. This research tries to answer the following questions: did the propensity of firms from emerging countries to engage in earnings management change after the financial crisis? How did the global financial crisis impact the extent of these developing firms' earnings management strategies? At the same time, the entry of these countries into the global and European market also affected local companies by exposing them to new turbulent and risky environments and competition with well-established Western European companies with more financial resources. Furthermore, these companies were forced to make the adjustments to how they present themselves. They, for example, can try to appear more competitive than they actually are. Other possibility is to manage earnings and to appear as weaker company and perceive certain benefits from the European accession.

The study contributes to the literature in three ways. First, it examines the impact of the global financial crisis on how firms' in the chosen countries manipulated financial results. In late 2007, the world financial crisis began, and the first impacts of the crisis on the economic environments of the countries were perceived in early 2008. Advanced economies struggled to maintain economic activity and were shaken by the instability caused by the recession. Emerging economies were also impacted as the deterioration in the economic environment caused considerable concern around the globe. Different authors have focused on similar questions; nevertheless, most of the previous papers published on the topic focus on the US, Asia or Western European countries.

Second, this research tries to explain how accession to the European Union affected the extent of earnings management in companies from developing countries. The accession of emerging Eastern European countries to the European Union resulted in new institutional, technological, and economic challenges for firms operating in these countries. This raises the question of how managers have responded to the complex and altered market environment. Important and fundamental changes have taken place in the economic and social structures in these countries. Additionally, from the point of view of researchers, it is important to explore the scope of earnings management by taking into account the whole European Community and not only the western part of the European Union. 
Finally, earnings management based on companies from emerging European countries is still barely explored. It is our purpose to fill the research gap in earnings management studies. Most European studies are based on the Western European countries. Incorporating Eastern European countries into the investigation of earnings management may allow for analyses on the broad impacts of earnings management on all of Europe (see for example, Balcerowicz, 1994; Jaruga and Ho, 2002). Developing Eastern European countries are still not at the same economic level as Western European countries. We can confirm that there is still a large gap between both regions ${ }^{1}$. Eastern Europe continues to adapt to the EU model through constant transformation and development. Given these economic circumstances, it could be expected that there are also possible differences in earnings management between Eastern and Western European countries. Consequently, an investigation into earnings management in these growing markets is needed.

Our study investigates earnings management in the companies from four developing Eastern European countries (Poland, Hungary, Slovakia, and the Czech Republic) during the period from 2003 to 2009. We test our research hypothesis with a methodology based on discretionary accruals. We compare the discretionary part of accruals before and after two events (i.e., accession to the European Union and the financial crisis).

Our findings suggest that earnings management has changed over the years. Managers of Eastern European companies manage their earnings by responding to the changes in their companies' environments. We detect two tendencies. From 2003 to 2007, we observed a moderate but continuous decrease in earnings management in companies from the emerging Eastern European countries, which can be explained by the accession of these countries to the European Union. We confirm that over different phases of the accession process earnings management decreased. In other words, companies from developing Eastern European countries gradually reduced earnings management in this period.

Additionally, we detect an increase in earnings management between 2008 and 2009. We find that earnings management significantly increased in the crisis years.

These results contribute to the debate in the literature about the effect of general economic conditions on earnings management in developing European countries. More specifically, they demonstrate that earnings management is more common during crises than growth periods. This finding should be of interest to academics, practitioners, and investors.

1 See evolution of the Gross Domestic Product, inflation, interest rate, unemployment rate, minimum wages, among other statistics. Consult the following databases: Eurostat (2015), World Bank database (2015), World Economic Outlook Database (2015). 
The remainder of this paper is organized in the following manner. First, we present a brief review of the literature and focus on studies on earnings management related to the effects of environmental circumstances, especially the global financial crisis and European Union membership. Next, we present the sample of countries and explain the methodology we employed. We then discuss the results. The next section discusses other studies based on emerging countries from other regions of the world. We compare their results with our study. Finally, we present the conclusions of the findings and their implications for further studies.

\section{Literature review}

Revelations of misrepresentations of financial statements have drawn attention to the reasons for such behavior. Some authors believe that managers always have an incentive to control information (see for example, Dechow and Sloan, 1991; Holthausen, Larcker and Sloan, 1995; Shackleford and Shevlin, 2001). However, in some circumstances, incentives may change depending on companies' external environments. Lim, Ding, and Thong (2008) argue that a dynamic environment is one of the factors that can influence managers' decisions. Thompson (1967) and Terreberry (1968) add that the complexity of the environment is important for managers' decisions. Kothari, Leone, and Wasley (2005) also argue that environmental uncertainty is likely to affect firm performance.

The general circumstances facing a firm are constantly changing. Managers must respond to these changes. They must try to cope with the fluctuations of the market, and they must also respond to these fluctuations through variations in earnings management. Richardson (2000) shows that earnings management changes due to the level of risk taken by firms. Therefore, some sets of relationships and circumstances may lead managers to engage in earnings management; however, other sets of macroeconomic factors may significantly limit the behavior of the managers.

There is an ongoing debate about whether and how economic cycles (especially the effects of crises) influence managers to misrepresent financial information by carrying out earnings management. Johnson (1999) and Chen (2010) state that firms' earnings volatility is correlated with economic cycles ${ }^{2}$. In the abundant studies on earnings management, the authors underline the influence of economic cycles on the existence of earnings management. Two main tendencies are observed.

The first group of papers demonstrates that when the economy, as a whole, is performing well, managers will be under pressure to report increased earnings.

2 The economic cycle is understood as a natural fluctuation of the economy between periods of expansion (growth) and recession (crisis). It may easily affect executives' decisions; see for example, Ohn, Taylor, and Pagan (2004); Lee, Lee, and Mason (2006); Dustmann, Glitz, and Vogel (2009), among others. 
Therefore, managers of firms that perform more poorly than their peers in good times will be penalized by markets if their reported earnings fail to meet expectations. Alternatively, when the economy as a whole is not performing well, the penalty for not reporting positive results might not be as severe as that during good times (Cohen and Zarowin, 2007). This simple logic predicts that managers' concerns and performance evaluations will provide incentives to inflate earnings in good times (Cohen and Zarowin, 2007). Similarly, Conrad, Cornell, and Landsman (2002) state that the tendency of firms to inflate earnings is greater during good times than during the bad times. Thus, firms face greater incentives to avoid poor earnings when the economy is strong, so they are more prone to boost earnings during such periods. Other authors (such as Khurana et al., 2006, and Rajgopal, Shivakumar, and Simpson, 2007), confirm the above hypothesis that earnings management increases during good times, and the market's response to bad news is most severe during good times.

At the same time, in a period of economic stress, managers are less likely to manipulate their earnings. Cimini (2015), for example, demonstrates that after a financial crisis, there is a reduction in earnings management. He analyzed a sample of non-financial entities listed in the $15 \mathrm{EU}$ countries. He is reasonably confident about the reduction in earnings management during the crisis because, on the one hand, the increase in conditional conservatism during the financial crisis should raise earnings quality and impair earnings management; on the other hand, the close monitoring by auditors during the crisis contributed to an increase in the quality of financial reporting, which reduces earnings management. Filip and Raffournier (2011) also confirm that managers are less likely to manage earnings in crisis years. They analyzed the impact of the 2008-2009 financial crisis on earnings management based on a sample of 16 European countries.

A second group of studies shows a different tendency, documenting that in periods of prosperity, less earnings management is expected, and during periods of distress, more earnings management is likely. Ahmad-Zaluki, Campbell, and Goodacre (2009), for example, provide evidence for earnings management during a period of economic distress. They provide two main explanations for the results. First, during a crisis, companies cannot use subsidiaries as financial buffers. Second, more attention is paid to financial stability than financial reporting transparency. Conrad, Cornell, and Landsman (2002) also state that during periods of crisis, managers are more likely to manage their earnings to cover their financial gaps and fulfill the companies' objectives. Managers may try to smooth the effect of fluctuations in the markets because, as explained by Baulkaran and Asem (2012), the market reacts more adversely to negative earnings news. Strings of news are important determinants of investors' reactions when markets are stable, and the effect of market transitions on investor overconfidence drives reactions during market transitions (Bhattacharya, 2001; 
Baulkaran and Asem, 2012). Hence, managers may mitigate the negative impacts of economic situations by inflating earnings.

Callao and Jarne (2011) also show that earnings-increasing discretionary accruals increased during the crisis, confirming that crisis periods affect financial reporting quality. The crisis strengthened some incentives to manage earnings, such as indebtedness. Finally, Ball and Shivakumar (2005) suggest that the lower levels of earnings management in recession periods may also result in conservative reporting.

European Union membership allows for free trade between the countries of Eastern and Western Europe. Managers of the companies from Eastern European countries may try to manage their earnings to seem stronger/weaker depending on the situation; they may do this to be able to compete in the European market. According to Moravcsik (1998), increased membership in the European Union helps increase opportunities for cross-border trade and capital movements, but at the same time, it creates opportunities for earnings management. Dijmarescu (2001) points out that membership is not a matter of the timing of the initiated negotiations. It is rather a matter of the readiness, determination, and changes made by the candidate countries to adhere to the free market and the rule of law, irrespective of political decisions reached by the EU toward its eastward extension (Dijmarescu, 2001). Therefore, this determination may lead to the existence of earnings management. In practice, managers are able to choose methods and make estimations that do not reflect the true economic position of their companies in order to provide more positive images of their companies (Healy and Wahlen, 1999).

However, it is perceived as shrinking the possibilities for managing results, as candidate states implement numerous legislative measures as a result of political pressure from the European Commission. During the transition period, new EU member countries are active in reviewing and amending key legislation to adapt new European requirements. The EU Commission proposes principles to improve regulations, such as the development and implementation of national anticorruption strategies or programs covering both preventive and repressive measures; the creation of competent and visible control bodies; the development of targeted investigative techniques, statistics, and indicators; and the implementation of clear and transparent rules on party financing, and external financial control of political parties (Dionisie and Checchi, 2010).

\section{Methodology}

\subsection{Sample and analysis period}

We examine four developing Eastern European countries (Poland, Hungry, Slovakia, and the Czech Republic), as the issue of earnings management in devel- 
oping Eastern European countries has been barely explored. We found only a few studies based on Eastern European countries, and most of them are descriptive and based on Polish companies (see Table 1).

The analysis covers the period of 2002 to 2009 because we are interested in evaluating the managers' engagement in earnings management just before accession to the European Union (i.e., 2002-2004). Eastern European companies were developing, growing, and making transformations over more than 10 years after the collapse of communism. It may be interesting to observe the effect of these transformations on existence of earnings management by companies from these countries.

In May 2004, these four Eastern European countries acceded to the European Union. The accession and its initial impact from 2005 to 2007 may be very important in terms of the engagement and scope of earnings management by managers in these countries. Furthermore, we are interested in evaluating the managers' activity in the period affected by world financial crisis, and whether during that period, managers are more/less likely to engage in earnings management. The initial impact of the global financial crisis occurred during the period of 2008-2009.

Our study contains both listed and unlisted companies. Nevertheless, our sample focuses mainly on unlisted private companies, as the financial sectors of listed companies in our sample countries are still in progress, growing, and flourishing very slowly.

For several decades, earnings management among public firms has been studied extensively in accounting literature while earnings management in private companies has not been investigated. However, private firms make up the foundation of the global economy and play an important role in economic growth, since they are major contributors to employment, entrepreneurship, and innovation worldwide (Sundvik, 2017).

Table 1: Country of earnings management investigation.

\begin{tabular}{|l|c|}
\hline Country of investigation & № of studies \\
\hline US & 99 \\
\hline China & 17 \\
\hline Spain & 11 \\
\hline Malaysia & 5 \\
\hline Japan & 4 \\
\hline Taiwan & 4 \\
\hline Finland & 4 \\
\hline UK & 4 \\
\hline Poland & 4 \\
\hline
\end{tabular}




\begin{tabular}{|l|c|}
\hline Country of investigation & № of studies \\
\hline Germany & 3 \\
\hline Korea & 3 \\
\hline Brazil & 3 \\
\hline Belgium & 2 \\
\hline Hong Kong & 2 \\
\hline Australia & 2 \\
\hline Netherlands & 2 \\
\hline France & 1 \\
\hline Pakistan & 1 \\
\hline Indonesia & 1 \\
\hline Iran & 1 \\
\hline Bangladesh & 1 \\
\hline Greece & 1 \\
\hline Canada & 1 \\
\hline Italy & 1 \\
\hline Rumania & $\mathbf{1 8 0 *}$ \\
\hline
\end{tabular}

* Table presents research on earnings management based on a sample from a single country. It is a common practice of researchers to use a one-country selection sample. In total, we may observe 180 studies within the period of 1981-2012. Additionally, we confirm 11 descriptive studies, and 16 additional studies with a multi-country sample. Callao, Jarne and Wroblewski (2014) called these last studies: panel studies or comparative studies.

The Czech Republic, Hungary, Slovakia, and Poland are among the eight Central and Eastern European countries that became new member states of the European Union on May $1^{\text {st }}, 2004$. These countries are transition economies. The transition process involved a set of reforms including privatization, labor market reform, the development of capital markets, price liberalization, currency convertibility, macroeconomic stabilization, and welfare reform (Kosmala, MacLullich and Gurau, 2004). Complex and dynamic changes brought about a need for thorough reform of the accounting systems in these countries, which was intended to reinforce the foundations of the new market economy (i.e., accountability, profitability, and transparency) (Kosmala, MacLullich and Gurau, 2004).

The key factors that determined the direction of the reforms were the specific geographic locations of the countries (i.e., the proximity to the European Union) and the need to attract foreign investments. As the countries strived to integrate with the European Union and attract foreign capital, the harmonization of their national financial reporting systems with the European directives and later with the International Accounting Standards framework became a crucial issue. Con- 
sequently, new regulations have successively incorporated the provisions laid out in the EU directives. Much attention was paid to achieving greater transparency and enhancing the quality of financial statements through the extension of the reporting requirements (Kosmala, MacLullich and Gurau, 2004). Therefore, we use non-consolidated financial statements prepared under local GAAP. Nevertheless, the financial statements are prepared under EU directives, which ensure the reliability of the reports ${ }^{3}$.

The directives leave some room for discretion due to explicit and implicit options. Furthermore, in some systems, some accruals may be considered as discretionary, while in others, the same accruals might be considered as non-discretionary. However, the literature still considers Eastern European countries as unique economic structures facing the common EU legal framework (see, for example, Prochazka, 2017).

Additionally, during the analysis period, the IFRS was not required, and different studies examining developing countries confirm that the introduction of the IFRS does not necessarily influence earnings management by private companies. In particular, it does not reduce earnings management, as may be expected (Kersten, 2011). Hasan and Rahman (2017) also confirm that the outcome of IFRS adoption is not conclusive to determine its influence on earnings management for a sample of developing countries. Results presented by Doukakis (2014), as well as, suggest that mandatory IFRS adoption had no significant impact on either real or accrual-based earnings management practices. Finally, Aussenegg, Inwinkl and Schneider (2008) verified that for companies from developing countries, the transition from local GAAPs to IAS/IFRS does not change earnings management behavior.

3 New accounting system in Slovakia became reality in 1991, Act no. 563/1991; and it became effective on January 1, 1993. In 2003 the Slovak Republic prepared a new act: Act No. 431/2003 on Accounting, which harmonized Slovak accounting with the directives of the EU.

In Hungary, accounting requirements have been regulated by law since 1991. Then, another act, the Act on Accounting (Act C of 2000) came into effect on January 1, 2001. This act brought Hungarian financial reporting practices closer to the International Financial Reporting Standard (IFRS), especially in line with the EU 4th and 7th Directives.

First accounting framework in the Czech Republic was based on the Act. No. 563/1992 Coll. After that, there was an important number of normative implemented to the Accounting Act in terms of the adjustment to the EU directives, such as: recognition of the items of a financial statement, for example: Entrepreneurs (No. 500/2002 Coll.); Financial institutions (No. 501/2002 Coll.); Commercial insurance companies (No. 502/2002 Coll.); Health insurance companies (No. 503/2002 Coll.); Non-profit organizations (No. 504/2002 Coll.); Governmental: public units (No. 410/2009 Coll.), among others.

Finally, in Poland, first, accounting was regulated by the Accounting Act of 29 September 1994. Then, in 2002 major amendments entered into force to adjust to EU directives. It was a preparation of the adaptation of legal regulations to directives and IFRS between 2011 and 2014. 
Our initial sample of companies was composed of a total of 4,627 non-financial firms, yielding 32,389 firm-year observations over the period of 2002-2009. We have only retained those firms for which data were available for the variables considered for all the years included in the study (2003-2009) and for the prior period (2002) used to calculate changes in certain variables. For each variable, we eliminated outliers, which are observations falling outside the range set by the mean value plus/minus three times the standard deviation. The data were collected using the AMADEUS database. Our final sample is presented in Table 2 .

Table 2: Sample selection procedure.

\begin{tabular}{|c|r|r|r|r|c|}
\hline & Czech $\boldsymbol{R}$. & Poland & Hungary & Slovakia & Total \\
\hline $\begin{array}{c}\text { Total number of firms available in } \\
\text { Amadeus database }\end{array}$ & 3,006 & 2,609 & 183 & 398 & 6,196 \\
\hline Incomplete data (missing data) & $(779)$ & $(208)$ & $(62)$ & $(163)$ & $(1,212)$ \\
\hline Extreme values & $(178)$ & $(150)$ & $(7)$ & $(22)$ & $(357)$ \\
\hline Total sample firms & $\mathbf{2 , 0 4 9}$ & $\mathbf{2 , 2 5 1}$ & $\mathbf{1 1 4}$ & $\mathbf{2 1 3}$ & $\mathbf{4 , 6 2 7}$ \\
\hline Number of observations & 14,343 & 15,757 & 798 & 1,491 & 32,389 \\
\hline
\end{tabular}

\subsection{Methodology}

\subsubsection{Measurement of earnings management}

We use a methodology based on accruals to detect and estimate the discretionary part of accruals. Accruals are defined as the part of revenues and expenses that do not imply collections and payments, and are indirectly calculated as the difference between profit and operating cash flows ${ }^{4}$. Total accruals are composed of non-discretionary accruals (NDA), which are the part of accruals that are difficult to manipulate, and discretionary accruals $(D A)$, which are easier to manipulate; therefore, $T A=N D A+D A$.

Since the discretionary and non-discretionary components of accruals are not directly observable, we use a cross-sectional version of the model employed by Yoon and Miller (2002)

4 The equation is: $T A_{i t}=\Delta$ Re ceivables $_{i t}+\Delta$ Inventories $_{i t}-\Delta$ Payables $_{i t}-D E P_{i t}$. It is used to calculate total accruals (TA). $\triangle$ Receivables is the change in receivable accounts; $\triangle$ Inventories is the change in inventories; $\triangle$ Payables is the change in payable accounts; and DEP is the depreciation and amortization expenses. The subscripts $i$ and $t$ refer to the firm and the year respectively. Variations are calculated with respect to the prior year.

5 Based on the previous research (working paper from 2016), we have evaluated the robustness and effectiveness of thirteen models for measuring earnings management, both for time-series and cross-sectional analysis: the Healy Model (1985), the DeAngelo Model (1986), the Jones Model (1991), Dechow, Sloan and Sweeney Model (Modified Jones Model) (1995), the Kang and Sivaramakrishnan Model (1995), the Shivakumar Model 


$$
\begin{aligned}
& \frac{T A_{i t}}{A_{i t}-1}=\alpha_{0} \frac{1}{A_{i t-1}}+\alpha_{1} \frac{\Delta R E V_{i t}-\Delta R E C_{i t}}{A_{i t}-1}+\alpha_{2} \frac{\Delta E X P_{i t}-\Delta P A Y_{i t}}{A_{i t}-1}(1) \\
& +\alpha_{3} \frac{N C A S H_{i t-1} \times G P P E G R W_{i t}}{A_{i t}-1}+\varepsilon_{i t}
\end{aligned}
$$

where $T A_{i t}$ is total accruals in year $t$ booked by firm $i$ in period $t ; \Delta R E V_{i t}$ is the change in net sales revenue; $\Delta R E C_{i t}$ is the change in receivable accounts; $\triangle E X P_{i t}$ is the change in operating expenses, excluding non-cash expenses; $\triangle P A Y_{i t}$ is the change in payables; $N C A S H_{i t-1}$ is previous period non-cash expenses, such as depreciation; GPPEGR $W_{i t}$ is a rate of growth in gross property, plant, and equipment; $A_{i t-1}$ is total assets from the previous period and is used as a deflator to avoid problems of heteroscedasticity; and $\varepsilon_{i t}$ is the error term.

After estimating the parameters of equation (1), we applied the values obtained to predict discretionary accruals for the 2003-2009 period. The prediction error is interpreted as the discretionary part of accruals, defined in equation (2):

$$
\begin{aligned}
& \frac{D A_{i t}}{A_{i t}-1}=\frac{T A_{i t}}{A_{i t-1}}-\left(a_{0} \frac{1}{A_{i t}-1}+a_{1} \frac{\Delta R E V_{i t}-\Delta R E C_{i t}}{A_{i t-1}}+a_{2} \frac{\Delta E X P_{i t}-\Delta P A Y_{i t}}{A_{i t}-1}\right. \text { (2) } \\
& \left.+a_{3} \frac{N C A S H_{i t-1} \times G P P E G R W_{i t}}{A_{i t-1}}\right)
\end{aligned}
$$

where $D A_{i t}$ are discretionary accruals for firm $i$ in period $t$, and $a_{0}, a_{1}, a_{2}$ and $a_{3}$ are the estimated values of $\alpha i$.

After obtaining the discretionary accruals for each company, we investigated whether companies from emerging Eastern Europe perform earnings management. Then taking into consideration the absolute value of the discretionary accruals, we ran Friedman's test ${ }^{6}$ to see if earnings management varies over the period in the different countries. We also confirmed that the variables do not follow a normal distribution (see Annex 1).

(1996), the Key Model (1997), the Teoh, et al. Model (1998), the Kasznik Model (1999), the Yoon and Miller Model (2002), the Dechow, Richardson, and Tuna Model (2003), the Larcker and Richardson Model (2004), the Kothari et al. Model (2005). Based on the adjusted R square, standard error of the estimated variables, and the $\mathrm{p}$-value, which represents the statistical significance of the variables, the results indicated that the cross-sectional Yoon and Miller model (2002) is an effective model for the Eastern European countries in detecting earnings management. We have observed higher level of adjusted $\mathrm{R}$ square, lower level of standard error, and more significant values of the parameters in comparison to other models.

6 Friedman's Test is a non-parametric test used to test for differences between groups (see, for example Stevens, 1986; Hinkle, Wiersma and Jurs, 1988; Hayes et al., 1992). 


\subsubsection{Model specification: environmental factors influencing earnings management}

Based on the large earnings management literature, ${ }^{7}$ we first identified variables that may explain changes in earnings management over time. We then created a linear regression model to examine how each variable affects firms' decisions to manage earnings. In the linear regression model the dependent variable is the absolute value of discretionary accruals $(|D A|)$ because we want to measure the magnitude of earnings management without regard to its sign. We estimate the coefficients of the variables by maximum likelihood using an ordinary least squares regression.

Between 2004 and 2007 Eastern European countries took steps towards European Union membership. Therefore, our first variable $\boldsymbol{A D A P T E U}$ accounts for accession period of these countries. The accession of Poland, the Czech Republic, Hungary, and Slovakia began in May 2004. Therefore, we differentiate possible periods that may have different influences on managers' decisions regarding earnings management. The first period of 2003-2004 included the process of preparation for EU membership. Then in 2005 and 2006, these countries began adapting to European standards. Finally, the countries became full members between 2007 and 2009. Two dummy variables are introduced to the model; the first dummy represents the preparation period of 2003-2004, and the second dummy variable designates the period of 2005-2006.

According to previous studies, European Union membership may significantly limit earnings management because of the new requirements of the European Union. Eastern European countries were not obliged to adopt IFRS in our sample period, as mentioned in previous section, but they made adjustments to investors' requirements and to international regulation that required additional relevant information. Ewert and Wagenhofer (2005) explain that tighter accounting standards and clearer rules increase earnings quality; they also decrease the likelihood of earnings management in companies. Additionally, detailed accounting standards may add value to accounting information (Bartov and Mohanram, 2004; Hung and Subramanyam, 2007; Barth, Landsman and Lang, 2008; Rudra and Bhattacharjee, 2012).

Furthermore, managers of the companies from Eastern European countries may have incentives to increase earnings management to be able to compete in the European market. Managers of firms from Eastern European countries may try to improve their earnings to seem stronger and because accounting regulation permits the manager to make judgments; for example, there are accounting gaps and the possibility of making accounting choices. Managers can make certain choices in financial reporting. In theory, companies should select accounting

7 We made a revision of 207 papers on earnings management. 
methods and make estimations that best reflect the economic position of the company (Kempen, 2010). In practice, managers are able to choose methods and make estimations that do not reflect the true economic position of their companies but create more positive images to outsiders (Healy and Wahlen, 1999); these actions are possible even within the permitted regulatory framework. Therefore, we do not expect positive or negative coefficients.

The global financial crisis began in 2008-2009. The initial effects were seen during this period. The literature confirms that fluctuations in the economy affect companies' activities. Firm's earnings fluctuations are correlated with economic cycles in general; see, for example, Johnson (1999), Conrad, Cornell and Landsman (2002), Jin (2005), Cohen and Zarowin (2007), Khurana et al. (2006), and Chen (2010), among others.

Jin (2005), for example, shows that the aggregate extent of earnings management is larger during recessions than during expansion. The author explains this situation with the fact that, in very weak economic periods, managers tend to engage more in earnings management. In very strong economic periods, managers may manage their earnings less (Jin 2005).

Conrad, Cornell, and Landsman (2002) and Cohen and Zarowin (2007) demonstrate that during periods of crisis, managers manage earnings more to fulfill their companies' objectives. Managers may try to mitigate the effects of economic fluctuation because, as explained by Baulkaran and Asem (2012), the market reacts adversely to fluctuations in earnings.

However, Chia et al. (2007) and Cimini (2015) give reasons to believe that earnings management is less common in crises than expansions. It can be argued that during crises, firms are subjected to increases in monitoring by auditors, creditors, and other stakeholders, which should result in less discretion to manage earnings.

Based on these findings, our second variable is a CRISIS dummy variable, which is 1 if the company's observation is from the period of 2008-2009 (the global financial crisis) and 0 otherwise. Based on the literature, we predict a positive relationship between the level of earnings management and this dummy variable. In periods of crisis, companies from developing countries are expected to increase earnings management as a response to the economic adversity.

Third, the influence of taxes on companies has largely been considered a strong stimulus for discretion by managers in financial statements. The literature demonstrates the importance of the effect of tax incentives on earnings management. Many studies have found evidence of earnings management for tax purposes. In Eastern European countries, the tax and financial reporting systems are closely connected, as a consequence of the strong influence of taxation on accounting. This connection comes from the development of the relationship be- 
tween taxation and accounting in recent decades; there was a long absence of specific accounting legislation until the $1990 \mathrm{~s}$. Companies in the former centrally planned economies were largely unaware of the scale of the taxes they paid through the turnover and payroll systems (Tanzi, 1999). Therefore, we include the $\boldsymbol{T A X}$ variable, as the tax environment may be still a strong stimulus for earnings management.

Finally, we include two variables to describe the macroeconomic conditions of Eastern European countries. The macroeconomic performance of countries is an institutional factor, and its relation to earnings management has been analyzed by, for example, Robson (1996), Clayton and Giesbrecht (1997), Leuz, Nanda and Wysocki (2002), Higson, Holly, and Kattuman (2002), Jin (2005), Tylsch 2009, and Broadstock, Shu, and Xu (2011), among others.

Broadstock, Shu, and Xu (2011) explain that the purpose of including macroeconomic information is to consider factors which may reduce the subjectivity of managers' decisions because companies' performances are also reflected by economic activity. Leuz, Nanda and Wysocki (2002) demonstrate that the macroeconomic environment can potentially affect firms. Differences in macroeconomic stability across countries may systematically impact the variability of accounting earnings. Higson, Holly, and Kattuman (2002) find evidence for the impact of changes in the macroeconomic environment on different segments of companies (Higson, Holly, and Kattuman, 2002) and on firms' earnings management behavior (Jiang, Fan and Fan, 2010; Bratten, Payne and Thomas, 2013). Robson (1996) demonstrates that movements in the aggregate failure of a firm's activity may coincide with changes in macroeconomic performance; for example, uncertainty can induce growing firms to delay their decisions to invest in capital (Dixit, 1989; Lambrecht and Myers, 2007).

The first macroeconomic variable included is Gross Domestic Product (GDP). We use the natural logarithm GDP per capita for each country. Previous studies used this measure for macroeconomic conditions (see Fama, 1981; Veronesi, 1999, Chordia and Shivakumar, 2002; Johnson, 1999; Kothari, 2001, and Klein and Marquardt, 2006). We expect to find a negative relationship indicating that better local country markets constrain earnings management (i.e., low levels of earnings management are expected). Shen and Chih (2005) confirm that higher GDP per capita decreases the degree of earnings management. Chih, Shen, and Kang (2007) find that companies in richer countries are generally less likely to manage earnings.

Our second macroeconomic variable is unemployment (UNEMPLOYM) that is the rate of unemployment in each country. Broadstock, Shu, and Xu (2011) used this variable to measure macroeconomic conditions. We expect positive association between earnings management and unemployment; a high rate of unemployment indicates poor economic conditions and may lead to higher earnings 
management over time (increasing or decreasing earnings). Prior studies demonstrate that in poor economic conditions, firms will be motivated to make accounting choices that give them advantages, mitigate the fluctuations caused by financial distress, or appear to strengthen their financial positions (see, for example, Bernanke and Gertler, 1989; Kiyotaki and Moore, 1997; Lambrecht and Myers, 2007).

Table 3 shows the variables, their definitions and the expected signs.

Table 3: Variables definition and predicted sign of the coefficients of the independent variables.

\begin{tabular}{|c|c|c|}
\hline Variable & Definition & Expected sign \\
\hline \multicolumn{3}{|l|}{ Dependent variable: } \\
\hline$|D A|$ & Absolute value of discretionary accruals & \\
\hline \multicolumn{3}{|c|}{ Independent variables: } \\
\hline ADAPTEU & $\begin{array}{l}\text { The variable designates periods leading to Euro- } \\
\text { pean Union membership. Three periods can be ob- } \\
\text { served: } 2003-2004 \text { preparation for EU member- } \\
\text { ship; } 2005 \text { and } 2006 \text { process of adaptation to the } \\
\text { European rules and standards; } 2007-2009 \text { the pe- } \\
\text { riod of stabilization. Therefore, two dummy vari- } \\
\text { ables are introduced. }\end{array}$ & $?$ \\
\hline CRISIS & $\begin{array}{c}\text { Crisis is a dummy variable, which takes a value of } 1 \\
\text { if a company's observation is from the period of } \\
2008 \text { and } 2009 \text { (the global financial crisis) and } 0 \\
\text { otherwise. }\end{array}$ & + \\
\hline TAX & $\begin{array}{l}\text { TAX is defined as the tax on the revenues of each } \\
\text { company of each country. } \\
\qquad \frac{\text { TaxCosts } t}{\text { Revenues }_{t}}\end{array}$ & + \\
\hline GDP & $\begin{array}{l}\text { Gross Domestic Product is defined as the natural } \\
\text { logarithm of the GDP per capita of each country. } \\
\qquad \operatorname{lnGDP}_{t}\end{array}$ & - \\
\hline UNEMPLOYM & $\begin{array}{l}\text { UNEMPLOYM is the rate of unemployment in each } \\
\text { country by year. } \\
\text { \% Unemploym } t\end{array}$ & + \\
\hline
\end{tabular}

* where $t$ is a period from 2003 to 2009.

We also consider three control variables used in other studies (see Table 4). To control for size effects, we include firm size (SIZE) measured by the relation of the total assets in each company in each sample, by year and scaled by total assets from $t-1$. Studies on earnings management confirm that the size of com- 
panies has an impact on the existence of earnings management; see Dhaliwal (1988), Watts and Zimmerman (1990), Chaney and Jeter (1992), Burgstahler and Dichev (1997), Young (1999), Barton and Simko (2002), Dechow and Dichev (2002), Othman and Zhegal (2006), Acito (2011), and Paiva and Costa (2013), among others.

Table 4: Control variables.

\begin{tabular}{|c|c|}
\hline Variable & Definition \\
\hline \multirow{3}{*}{ SIZE } & SIZE is total assets scaled by assets from $t-1$ \\
\hline & Assets $_{t}$ \\
\hline & $\overline{\text { Assetst-1 }_{\text {t }}}$ \\
\hline LISTED & $\begin{array}{c}\text { LISTED is a dummy variable that equals } 1 \text { if firm is a listed company and } 0 \\
\text { otherwise }\end{array}$ \\
\hline INDUSTRY & $\begin{array}{l}\text { INDUSTRY is a variable that includes nine dummy variables according to the } \\
\text { one digit SIC codes; it takes values } 1 \text { if the firm belongs to the corresponding } \\
\text { industry (No }=1, \ldots, 9) \text { and otherwise } 0 \text {. Industry classification is presented in } \\
\text { Table } 8.3\end{array}$ \\
\hline
\end{tabular}

* where $t$ is a period from 2003 to 2009 ,

The second control variable, LISTED, accounts for whether firms are listed on the Czech, Polish, Hungarian, or Slovakian stock exchanges. It is a dummy variable taking the value 1 if a company is listed and 0 if not. The coefficient on LISTED captures the difference in the degree of earnings management between listed and non-listed firms in Eastern European countries. Previous studies suggest that listed and non-listed companies differ in managing earnings; see Rangan (1998), Beatty and Harris (1998), Vander Bauwhede and Willekens (2003), Jensen (2004), Ball and Shivakumar (2005), Burgstahler, Hail and Leuz (2006), Sundgren (2007), and Skarda (2010).

We also include the INDUSTRY variable. Following the literature, we measure the firms' industry with multiple dummy variables (nine dummies); each variable takes the value of 1 if a company belongs to the industry corresponding to that variable $\left(N^{o}=1, \ldots, 9\right)$ and 0 otherwise. Industry classification and the distribution of the companies in each industry in our four countries are described in Annex 2. According to the literature, a firm's industry is seen as an important variable in determining its accounting choices; see for example, Verrecchia (1983), Watts and Zimmerman (1986), Foster (1986), Porter and McGahan (1997), Beneish (2001), Palepu et al. (2004), Lin (2006), Lee (2007), Callao and Jarne (2011), and Datta, Iskandar-Datta, and Singh (2013). 
With these variables, we created the following model:

$$
\begin{aligned}
& |D A|=\beta_{0}+\beta_{1} A D A P T E U_{34}+\beta_{2} A D A P T E U_{56}+\beta_{3} C R I S I S+\beta_{4} T A X_{i t}(3) \\
& +\beta_{5} G D P_{i t}+\beta_{6} U N E M P L O Y_{i t}++\beta_{7} S I Z E_{i t}+\beta_{8} L I S T E D \\
& +\beta_{9} I N D U S T R Y_{1}+\ldots+\beta_{17} I N D U S T R Y_{9}
\end{aligned}
$$

The dependent variable, $|D A|$, is the absolute value of discretionary accruals of the firms, as mentioned. The explanatory variables are as follows:

- The ADAPTEUvariable includes two dummy variables that designate periods leading to European Union membership. We differentiate three main periods: 1) 2003-2004, the preparation for EU membership; 2) 2005 and 2006, the process of adaptation to the European rules and standards; and 3) 20072009 , the period of stabilization and entry into the membership structures, which we call the full membership period. For $A D A P T E U_{34}$, the variable takes the value of 1 if a company's observation is from the period of 2003 and 2004 and 0 otherwise; for $A D A P T E U_{56}$, the variable takes the value of 1 if a company's observation is from the period of 2005 and 2006 and 0 otherwise.

- CRISIS is a dummy variable, which takes a value of 1 if a company's observation is from the period of 2008 and 2009 (the global financial crisis) and 0 otherwise;

- TAX is defined as the tax on the revenues of each company of each country ${ }^{8}$;

- GDP is defined as the natural logarithm of the GDP per capita of each country;

- UNEMPLOYM is the rate of unemployment in each country by year;

- SIZE is total assets scaled by assets from $t-1$;

- LISTED is a dummy variable that equals 1 if firm is a listed company and, 0 otherwise;

- INDUSTRY is a variable that includes nine dummy variables according to the one digit SIC codes; it takes values 1 if the firm belongs to the corresponding industry $\left(\mathrm{N}^{\mathrm{o}}=1, \ldots, 9\right)$ and, otherwise 0 .

\section{Results}

\subsection{Analysis of earnings management}

We confirm that companies from emerging Eastern European countries manage their earnings. Annex 3 reports the descriptive statistics and detailed results of the regression parameters for discretionary accruals using the model from Yoon and Miller (2002).

8 Similar measure of tax variable was used in Lin, Lin, and Tsai (2004); Callao, Jarne, and Wroblewski (2017) for a sample of developing countries. 
Additionally, the results of the non-parametric Friedman's test verify that there are differences in earnings management over the period (see Table 5). The test also yields significant results (chi-squared statistic significant at the $1 \%$ level).

Table 5: Non-parametric Friedman's test results.

\begin{tabular}{|c|c|c|c|c|c|}
\hline & & $\begin{array}{c}\text { Czech Repub- } \\
\text { lic }\end{array}$ & Poland & Hungary & Slovakia \\
\hline Chi-Square & & $77.251^{* * *}$ & $87.184^{* * *}$ & $15.534^{* *}$ & $61.087^{* * *}$ \\
\hline & 2003 & 4.07 & 3.85 & 4.35 & 3.73 \\
\hline & 2004 & 4.13 & 4.34 & 4.38 & 3.57 \\
\hline & 2005 & 4.12 & 4.02 & 3.99 & 3.57 \\
\hline Mean & 2006 & 3.89 & 3.91 & 3.8 & 3.66 \\
\hline & 2007 & 3.66 & 4.06 & 3.54 & 4.48 \\
\hline & 2008 & 4.00 & 3.83 & 3.74 & 4.33 \\
\hline
\end{tabular}

* significance at the $10 \%$ level.

** significance at the $5 \%$ level.

*** significance at the $1 \%$ level.

Figure 1 : Tendencies of the earnings management in Eastern European countries over the years.

\begin{tabular}{|c|c|c|c|c|}
\hline & Czech Republic & Poland & Hungary & Slovakia \\
\hline 2003 & & & & \\
\hline 2004 & & & & \\
\hline 2005 & & & & \\
\hline 2006 & & & & \\
\hline 2007 & & & & $\Lambda$ \\
\hline 2008 & & 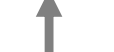 & 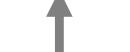 & \\
\hline 2009 & & & & \\
\hline
\end{tabular}

Source: The author, based on Friedman test. 
Moreover, we detected two main tendencies in our results: a gradual decrease in earnings management (mean ranks) in firms from our sample countries between 2003 and 2007 and a rise in earnings management between 2008 and 2009 (see Figure 1).

Both tendencies might be explained by the effect of joining the European Union by the four countries, and the impact of the global financial crisis which have started in late 2007 and in early 2008 affected economic environment worldwide. In the following section, we present the regression results.

\subsection{Regression results}

Table 6 presents the results of the regression 9 . The coefficient on the unemployment variable is insignificant. This indicates that the rate of unemployment is not significantly related to the scope of earnings management in companies from Eastern European countries and it cannot explain observed changes in earnings management over time. The other variables have coefficients that are significant the $1 \%$ (most of the variables) and $5 \%$ levels. We now present the influence of each independent variable on the scope of earnings management in firms from Eastern European countries over time.

Table 6: Results of ordinary least squares regression.

\begin{tabular}{|c|c|c|c|c|c|}
\hline \multirow[t]{2}{*}{ Variables } & \multicolumn{2}{|c|}{$\begin{array}{l}\text { Unstandardized Coeffi- } \\
\text { cients }\end{array}$} & \multirow{2}{*}{$\begin{array}{c}\text { Standardized } \\
\text { Coefficients }\end{array}$} & \multirow[t]{2}{*}{$\mathbf{t}$} & \multirow[t]{2}{*}{ Significance } \\
\hline & B & Std. Error & & & \\
\hline (Constant) & .033 & .046 & & .786 & .427 \\
\hline ADAPTEU34 & .008 & .003 & .032 & 3.295 & .001 \\
\hline ADAPTEU56 & .001 & .002 & .003 & .370 & .712 \\
\hline CRISIS & .017 & .002 & .064 & 8.382 & .000 \\
\hline TAX & -.003 & .012 & -.036 & 2.823 & .776 \\
\hline GDP & -.009 & .005 & -.026 & -1.905 & .057 \\
\hline UNEMPLOYM & .000 & .000 & -.006 & -.559 & .576 \\
\hline LISTED & .012 & .005 & .012 & 2.199 & .028 \\
\hline SIZE & .103 & .002 & .347 & 64.823 & .000 \\
\hline INDUSTRY1 & .014 & .004 & .034 & 3.744 & .000 \\
\hline INDUSTRY2 & 017 & .003 & .059 & 5.161 & .000 \\
\hline
\end{tabular}

9 We confirm that the model is well-specified. The adjusted $\mathrm{R}^{2}$ of the model is at the $13 \%$ level. This is a good result in terms of discretionary accruals models. Additionally, F-test confirms that the model is significant $(\mathrm{F}=302.788)$. Other authors obtained similar results of adjusted $\mathrm{R}^{2}$, see for example, Liu and Ziebart (1999) $\mathrm{R}^{2}=8.4 \%$; Koh (2003) $\mathrm{R}^{2}=12.86 \%$; Louis (2004) $\mathrm{R}^{2}=10.71 \%$; Guan, Wright and Leikam (2005) $\mathrm{R}^{2}=11.06 \%$; Bergstressera and Philippon (2006) $\mathrm{R}^{2}=8.2 \%$; Liu and $\mathrm{Lu}(2007) \mathrm{R}^{2}=7.48 \%$. 


\begin{tabular}{|c|c|c|c|c|c|}
\hline \multirow[t]{2}{*}{ Variables } & \multicolumn{2}{|c|}{$\begin{array}{l}\text { Unstandardized Coeffi- } \\
\text { cients }\end{array}$} & \multirow{2}{*}{$\begin{array}{c}\begin{array}{c}\text { Standardized } \\
\text { Coefficients }\end{array} \\
\text { Beta }\end{array}$} & \multirow[t]{2}{*}{$t$} & \multirow[t]{2}{*}{ Significance } \\
\hline & B & Std. Error & & & \\
\hline INDUSTRY3 & .006 & .004 & .014 & 1.665 & .096 \\
\hline INDUSTRY4 & .030 & .003 & .129 & 9.341 & .000 \\
\hline INDUSTRY5 & .015 & .005 & .019 & 2.959 & .003 \\
\hline INDUSTRY6 & -.003 & .004 & -.006 & -.754 & .454 \\
\hline INDUSTRY7 & .028 & .004 & .043 & 6.179 & .000 \\
\hline INDUSTRY8 & .003 & .004 & .006 & .667 & .505 \\
\hline INDUSTRY9 & .051 & .008 & .038 & 6.668 & .000 \\
\hline Adjusted $\mathrm{R}^{2}$ & & & 0.130 & & \\
\hline F-value & & & $302.788^{*}$ & & \\
\hline
\end{tabular}

$|D A|=\beta_{0}+\beta_{1} A D A P T E U_{34}+\beta_{2} A D A P T E U_{56}+\beta_{3} C R I S I S+\beta_{4} T A X_{i t}$ $+\beta_{5} G D P_{i t}+\beta_{6} U N E M P L O Y_{i t}+\beta_{7} S I Z E_{i t}+\beta_{8} L I S T E D$

$+\beta_{9} I N D U S T R Y_{1}+\ldots+\beta_{17} I N D U S T R Y_{9}$

ADAPTEU variable includes two dummy variables that designates periods leading to European Union membership. CRISIS is a dummy variable, which takes a value of 1 if a company's observation is from the period of 2008 and 2009, 0 otherwise. TAX is defined as the tax on the revenues. GDP is defined as the natural logarithm of the Gross Domestic Product per capita. UNEMPLOYM is the rate of unemployment. SIZE is total assets scaled by assets from $t-1$. LISTED is a dummy variable that equals 1 if the firm is a listed company and 0 otherwise. INDUSTRY is a variable that includes nine dummy variables according to the one digit SIC codes; it takes values 1 if the firm belongs to the corresponding industry ( $N N=1, \ldots, 9)$ and otherwise 0 .

\section{*Significant at $1 \%$}

\section{Phases in the adaptation process to European Union (ADAPTEU)}

The results demonstrate that there is a significant difference in terms of the scope of earnings management between the two periods preceding European Union membership of the four countries. The dummy variables provide a clear comparison of the three EU membership periods. We can see that the first period of preparation for EU accession (2003-2004) has a significant impact on the scope of earnings management over that period of time. The coefficient is positive and significant at the $5 \%$ level. It indicates that the circumstances of the first period incentivized managers to intensify earnings management (i.e., to increase or decrease earnings).

In the first period, companies from the four Eastern European countries found it necessary to improve their strategic positions. They were weaker, smaller, and, as a result, less competitive than their Western European counterparts. Indeed, they are still not at the same level as companies from Western European coun- 
tries. Gorynia (2005) explains that strategic position consists of the attractiveness of the markets in which firms operate and the competence of those firms in their respective fields. We confirm that the "unexpected" increment of the scope of the revenues was between $5 \%$ and $10 \%$ in more than $85 \%$ companies from all four developing countries. At the same time, we observed also an approximately 5-7\% decrease in total costs, which may indicate that firms were attempting to improve their strategic positions through earnings management.

Kempen (2010) explains that managers make certain choices to better reflect the economic positions of their companies. This is due to accounting regulations which permit managers to make judgments and, in practice choose methods and estimations that do not reflect the true economic positions of the company but provide more positive images (Healy and Wahlen, 1999).

We did not identify a significant influence of the second period on the extent of earnings management (the variable is not significant). This finding can be explained by the fact that during the period of adaptation, managers of firms from the four Eastern European countries focused on the fulfilment of European requirements, standards, and rules. European structures demand adjustments to accounting practices. As mentioned previously, the accounting framework in all countries has been updated to the EU directives. The accounting systems in Eastern European countries were outdated and needed important changes. Prior to accession, the accounting frameworks in Slovakia, Hungary, the Czech Republic, and Poland were based on laws from 1991, 1991, 1992, and 1994, respectively

Furthermore, detailed accounting standards add value to accounting information (Bartov and Mohanram, 2004; Hung and Subramanyam, 2007; Rudra and Bhattacharjee, 2012). However, the period before the EU membership may be characterized as transitional and, the adoption of IFRS was not complete.

Table 7: Audit regulations in various countries.

\begin{tabular}{|c|c|l|l|}
\hline Country & $\begin{array}{c}\text { Adoption of Directive } \\
\text { 2006/43/EC }\end{array}$ & Audit partner rotation & \multicolumn{1}{|c|}{$\begin{array}{c}\text { Disclosure of audit } \\
\text { fees }\end{array}$} \\
\hline Czech Republic & 2009 & $\begin{array}{l}\text { until 2008: no; since } \\
\text { 2009: yes (7 years) }\end{array}$ & $\begin{array}{l}\text { until 2008: no; since } \\
\text { 2009: yes }\end{array}$ \\
\hline Hungary & 2008 & $\begin{array}{l}\text { until 2007: no; since } \\
\text { 2008: yes (5 years) }\end{array}$ & $\begin{array}{l}\text { until 2007: no; since } \\
\text { 2008: yes }\end{array}$ \\
\hline Poland & 2009 & $\begin{array}{l}\text { until 2008: no; since } \\
\text { 2009: yes (5 years) }\end{array}$ & $\begin{array}{l}\text { until 2008: no; since } \\
\text { 2009: yes }\end{array}$ \\
\hline
\end{tabular}

*Slovakia has not been included in this study.

Source: Hess (2014). 
Finally, the last period represented by the dummy variable not included in the model ${ }^{10}$, had a lower level of earnings management than the other two periods. In this period, the companies were fully-integrated into the EU structure. Additionally, the control procedures in the EU were well-developed and sophisticated. Therefore, earnings management may have been significantly reduced by direct influence of the Western European investors or by audit control. Hess (2014) analyzes the audit regulation in 28 European countries and, its effect on the quality of financial statements. Different steps have been taken to improve the reliability of the financial statements; for example, external rotation is a measure to increase auditor independence and to improve audit quality. Another measure was the implementation of the Audit Directive 2006/437EC. Furthermore, Directive 2006/43/EC (European Parliament and European Council 2006), amended by Directive 2008/30/EC (European Parliament and European Council 2008), contains rules regarding statutory audits of annual accounts ${ }^{11}$. The main goal of the Audit Directive was to harmonize the audit processes across the EU member states and to establish a single market for audit services within the EU. As shown in Table 7, all four countries improved audit regulations by introducing the Audit Directive 2006/43/EC, audit partner rotation of disclosure of audit fees, among other measures; these actions confirm our results.

\section{Economic crisis variable (CRISIS)}

The CRISIS variable has a significant positive coefficient $(0.017)$, which is consistent with our prediction. Changes in the scope of the earnings management of Eastern European firms were influenced by the economic crisis. The positive sign of the coefficient of the variable indicates that during crises, it is expected that managers will increase earnings management (i.e., to increase or decrease earnings). On the other hand, when economic conditions improve a lower level of earnings management is predicted.

The global crisis impacted on the economic environment worldwide. Advanced economies were battling to maintain economic activities and were shaken by the instability of the markets caused by the recession. Emerging economies were also impacted as the deterioration in the economic environment caused considerable concern around the globe. Figure 2 shows some economic variables of the firms and the abrupt and unexpected decreases in the values of these variables between 2008 and 2009.

The financial crisis dramatically reduced the economic activity of companies from Eastern European countries; the economic crisis hit the emerging region of Eastern Europe in late 2008.

10 Regression model includes one less dummy variable than there are categories, to avoid multi-colinearity.

11 European Parliament and European Council, 2006. 
Figure 2: Economic variables: Total scaled assets (mean) by country
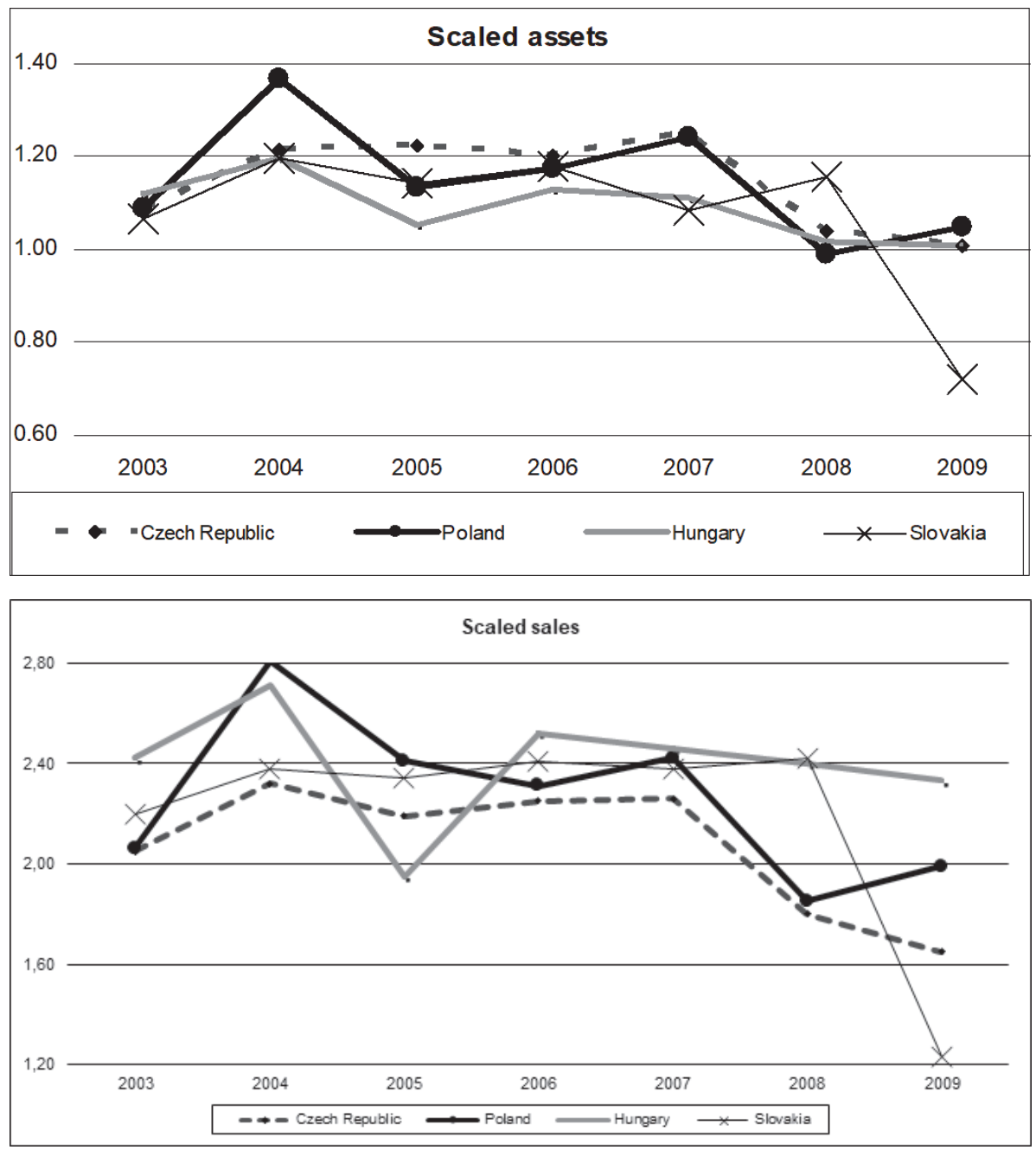


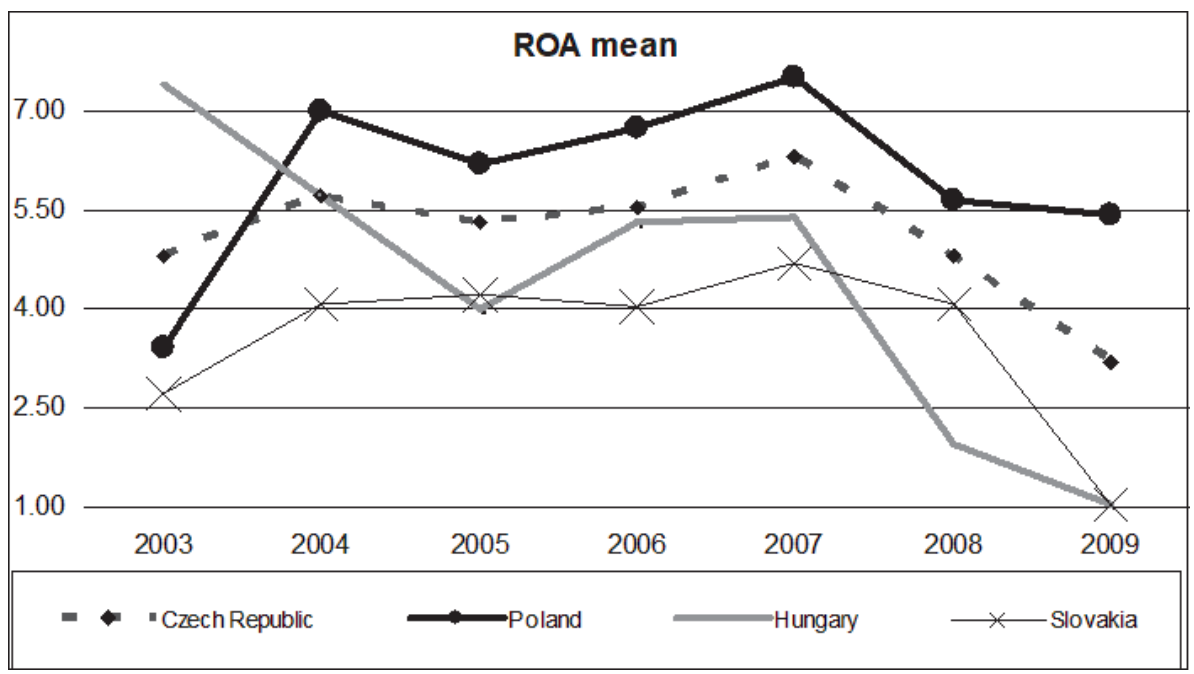

Source: The author

\section{Gross Domestic Product variable (GDP)}

The coefficient of the Gross Domestic Product variable is significant (at the $10 \%$ level) and negative (-0.009), representing the fact that the Eastern European countries' economic development affects managers' decisions to change their use of earnings management over time. The sign is in line with our prediction; strong local markets constrain earnings management.

\section{Figure 3: Gross Domestic Product per capita.}

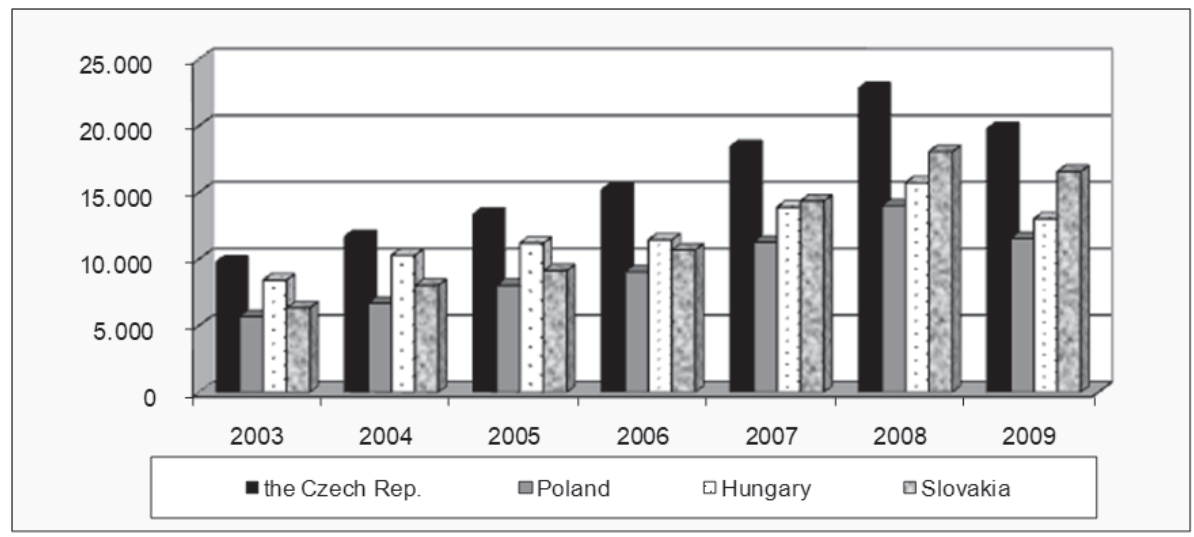

Source: The author. 
Figure 3 shows that when the economy of each country is growing (contracting), the scope of earnings management decreases (increases). In the last two years of the period, the GDP of the four countries decreased and, at the same time, earnings management increased.

The literature confirms our results; higher GDP per capita decreases the degree of earnings management (Shen and Chih, 2005). Jin (2005) demonstrates that the magnitude of earnings management fluctuates quarterly, and its variation can be predicted by real economic activity.

\section{Listed variable (LISTED)}

The listed variable is significant at the $5 \%$ level and has a positive coefficient (0.012). However, even though the security exchanges and financial sectors in the four countries are still relatively underdeveloped (Köke and Schröder, 2006), we confirm that fluctuations in earnings management depend on whether companies are listed. Table 8 shows the distribution of listed companies in each country over time. The positive sign indicates that earnings management is more common in listed firms than unlisted firms.

Such behavior may be connected to the visibility of firms. The threat of negative media publicity for listed companies may affect managerial practices (Bansal, 2005). Publicity generates pressure for firms to maintain stable development, strong earnings results, and positive images.

Table 8: Total of listed companies in Eastern European countries.

\begin{tabular}{|l|r|r|r|r|r|r|r|}
\hline Country & \multicolumn{1}{|c|}{$\mathbf{2 0 0 3}$} & \multicolumn{1}{|c|}{$\mathbf{2 0 0 4}$} & \multicolumn{1}{|c|}{$\mathbf{2 0 0 5}$} & $\mathbf{2 0 0 6}$ & \multicolumn{1}{|c|}{$\mathbf{2 0 0 7}$} & \multicolumn{1}{|c|}{$\mathbf{2 0 0 8}$} & \multicolumn{1}{c|}{$\mathbf{2 0 0 9}$} \\
\hline Czech Republic & 63 & 54 & 36 & 29 & 32 & 18 & 16 \\
\hline Poland & 203 & 225 & 248 & 267 & 328 & 349 & 354 \\
\hline Hungary & 49 & 47 & 44 & 41 & 41 & 41 & 43 \\
\hline Slovakia & 306 & 258 & 209 & 173 & 153 & 125 & 107 \\
\hline
\end{tabular}

Source: Doing Business database, 2012.

\section{Size variable (SIZE)}

Firm size is correlated with managerial decisions, and it indeed influences earnings management over time. The coefficient is positive (0.103) and significant. Our results confirm that firm size should also be considered when explaining the changes in the earnings management of Eastern European firms. We find that large firms have a higher level of earnings management, and small Eastern European firms have a lower level of earnings management over time. Large firms draw attention from the media, investors, and regulators, and regulation may be designed for specific industries or corporations (Paiva and Costa, 2013). There- 
fore, large firms are more likely engaged in earnings management for the purpose of their public visibility and political costs (Watts and Zimmerman, 1990). However, smaller companies can face the contrary situation, such as a lower pressure, no media expectations, lower information asymmetry, and no agency conflicts.

\section{Industry variable (INDUSTRY)}

Firm industry is an important variable influencing the use of earnings management by Eastern European managers; Annex 2 shows the industry distribution in our sample countries. Table 6 shows that in almost all sectors, the coefficients of the variables are significant. This means that fluctuations in earnings management can be explained to some extent by the industries firms operate in. A firm operating in one industry may have a different tendency to engage in earnings management than companies operating in other industries.

There is a large body of literature that confirms that a firm's industry is an important variable affecting accounting choices, as explained above. This is because industry earnings performance is often used as a benchmark for evaluating firm performance (Antle and Smith, 1986; Gibbons and Murphy; 1990); firms' earnings information affects other firms' earnings decisions via intra-industry earnings information transfers (Pyo and Lustgarten, 1990; Freeman and Tse, 1992). Firms are likely to delay their earnings announcements to observe other firms' earnings and assess industry conditions (Park and Ro, 2004).

\section{Tax variable (TAX)}

Our results have confirmed that in our sample, the earnings management of companies from the four emerging Eastern European countries is not affected by taxes. The coefficient on tax variable $(T A X)$ was not significant.

\section{Context and implication for other emerging countries}

Emerging European countries can be compared to other emerging countries from other regions. The literature defines an emerging market as a country that has some characteristics of a developed market but does not meet standards of a developed market (MSCI, 2012). The largest developing economies - Brazil, China, India, and Russia - and countries such as Indonesia, Mexico, South Korea, Malaysia, and Bangladesh are mentioned as examples of emerging economies. In Europe, the Czech Republic, Estonia, Greece, Hungary, Poland, Romania, Slovakia, and Slovenia are the main emerging countries. However, as mentioned in Section 3, there are almost no studies on European emerging markets. 
The prior literature also reports the existence of earnings management in emerging economies; for example, Razzaque, Rahman and Salat (2006) found earnings management in companies from Bangladesh; Lee and Xue (2004), Yu, Du, and Sun (2006), Liu and Lu (2007) found evidence for China; Yoon and Miller (2002), Kim and Yi (2005) found evidence for South Korea; Saleh, Iskandar, and Rahmat (2005) and Bukit and Iskandar (2009) found evidence for Malaysia; Caramanis and Lennox (2008) found evidence for Greece; Swiderski (2010) found evidence for the Czech Republic, Hungary, and Poland; and Matis (2010) found evidence for Romania.

There are few studies discussing earnings management in emerging economies during periods of crisis; however, these studies have also found evidence that financial crises influence managers' decisions to use earnings management. Eng et al. (2019), for example, found that in the Chinese economy, firms' earnings management activities differ in crisis and non-crisis periods. They compare the pre-financial crisis period and the post-financial crisis period and find important differences; they also show that earnings management is lower in Chinese family firms relative to non-family firms in the post-financial crisis period, but both engage in earnings management.

Mittal and Ajay (2019) demonstrate the strong impact of earnings management in the financial reporting of Indian companies during crisis years. Fernandes da Silva et al. (2014), based on a Brazilian sample, find that earnings management practices may aim both to reduce and increase the earnings during periods of crisis. Such a practice might be used, for example, to transfer poor results from prior periods or even to avoid government sanctions (e.g., withdrawal of some subsidies), covering a higher than expected performance. Such a practice may also be adopted to bring "good news" which could help firms retain or attract cautious investors.

Pozzoli and Parthenope (2018) investigated the Brazilian economy and found contrary results - that is, that a crisis might not produce an increase in earnings management practices. They found a possible explanation, as the Brazilian economy, despite the global crisis grew significantly during this period.

As for the tax variables, other studies on emerging countries do not confirm our results and instead show that tax incentives influence earnings management. Lin (2006), for example, confirms that Chinese firms' earnings management behavior is correlated with the tax incentives. Swiderski (2010), based on samples from the Czech Republic, Hungary, and Poland, also demonstrate that public and private firms' engagement in earnings management is also affected by taxes. Flores et al. (2016) observe that Brazilian companies with greater income tax 
burdens tend to improve their discretionary accruals and earnings management $^{12}$.

All these studies provide results that contradict those in our study, which was expected because tax incentives are widely considered to be determinants of earnings management. One possible explanation for our results is the changing tax practices of emerging Eastern European countries as they adopted more investor-oriented perspectives, as explained in Vellam (2004) and Sucher and Jindrichovska (2004). The market orientation approach clearly prioritizes investor perspectives rather than incentives regarding taxes (for example, reducing or increasing tax burdens).

We did not find studies on the influence of European membership and earnings management in other emerging countries. However, Yu, Du, and Sun (2006), for example, found empirical results indicating that Chinese firms changed their earnings management behavior in response to changes in regulatory requirements. Therefore, regulatory changes indeed impact firms' earnings management practices.

Finally, the macroeconomic conditions of emerging countries were analyzed by Chen et al. (2019). They found that Chinese firms in provinces with GDP growth lower than the national level were more likely to engage in earnings management than firms in other provinces. These results confirm our results finding that a strong local country markets may constrain earnings management.

\section{Conclusion}

The purpose of this paper was to investigate the influence of macroeconomic conditions on the earnings management of the companies from emerging Eastern European countries during the period of 2002-2009. In particular, we focused on whether and how the financial crisis affected the tendency of managers to manage earnings and the effect of European membership on the existence and scope of earnings management. We focused on four developing Eastern European countries (the Czech Republic, Poland, Hungary, and Slovakia) as these countries have been barely explored.

The main finding of this paper is that there was significant decrease in earnings management and an improvement of accruals quality in the period of European Union accession. During the period of adaptation to the EU requirements, managers of Eastern European companies may have focused on the fulfilment of European requirements, standards, and rules and complying with strict and de-

12 Other explanation may come from the way of measuring tax variable, other authors used tax-rate increase, marginal tax-rate, pretax accounting income minus fiscal profit scaled by total assets, income tax expenses divided by pre-tax income, etc. 
manding regulation. In the following years, new audit control procedures significantly reduced opportunities for earnings management.

Furthermore, we confirm that during the period of crisis, there was an increase in earnings management. This finding can be explained by the fact that in a period of crisis, when investors are pessimistic about earnings news, managers rely more on earnings management. Furthermore, despite the poor economic situation, they try report earnings similar to those in previous periods. Moreover, it is confirmed that during periods of crisis, managers may try to smooth the effect of fluctuations and opt for earnings management to fulfill their companies' objectives.

Although we have filled some gaps in earnings management literature, there are further issues to investigate. A potential extension to this research could be a comparative study of earnings management in Eastern and Western Europe to understand both markets. The issue of earnings management in Europe as a whole has so far remained unanswered.

It would be also useful to conduct the analysis in this paper using the sample of other developing countries in order to know whether the European evidence is unique.

Another possible extension could be to analyze the data for the four Eastern European countries using a different methodology to see if such approach can confirm our results.

Lastly, future research could compare our results with a sample of Eastern European companies that prepare financial statements under the IFRS to evaluate if the introduction of the IFRS has an effect on earnings management. This has not yet been done with a sample of developing Eastern European countries.

\section{Bibliography}

Acito, A. (2011). Does Quarterly Earnings Guidance Increase or Reduce Earnings Management?, Tippie College of Business, The University of Iowa, working paper, 1-43.

Ahmad-Zaluki, N., Campbell, K. and Goodacre, A. (2009). Earnings management in Malaysian IPOs: the East Asian crisis, ownership control and post-IPO performance, University of Utara and University of Sterling, working paper.

Antle, R. and Smith, A. (1986). An empirical investigation of the relative performance evaluation of corporate executives, Journal of Accounting Research Spring, 1-39.

Aussenegg, W., Inwink1, P. and Schneider, G. 2008. Earnings Management and Local vs. International Accounting Standards of European Public Firms, SSRN Electronic Journal, 152.

Balcerowicz, L. (1994). Transition to the market economy: Poland 1989-93 in comparative perspective, Econ. Policy, Suppl. 19, 57-100. 
Ball, R. and Shivakumar, L. (2005). Earnings quality in UK private firms: comparative loss recognition timeliness, Journal of Accounting and Economics, 39, 1, 83-128.

Bansal, P. (2005). Evolving Sustainably: A Longitudinal Study of Corporate Sustainable Development, Strategic Management Journal, 26, 197-218.

Barth, M., Landsman, W. and Lang, M. (2007). International Accounting Standards and Accounting Quality, Journal of Accounting Research, 46, (3), 467-498.

Barton, J. and Simko, P. (2002). The balance sheet as an earnings management constraint, The Accounting Review 77, 1-27.

Bartov, E. and Mohanram, P. (2004). Private information, earnings manipulations and executive stockoption exercises, The Accounting Review 79 (4): 889-920.

Baulkaran, V. and Asem, E. (2012). Market Movements and Investors' Reaction to Earnings News, working paper, 1-33.

Beatty, A. and Harris, D. (1998). The effects of taxes, agency costs and information asymmetry on earnings management, Review of Accounting Studies, 4, 299-326.

Beneish, D. (2001). Earnings Management: A Perspective, Managerial Finance, Volume 27,12, 3-17.

Bergstressera, D. and Phililippon, T. (2006). CEO incentives and earnings management, Journal of Financial Economics, 80, 511-529.

Bernanke, B. and Gertler, M. (1989). Agency costs, net worth and business fluctuations, American Economic Review, 79:14-31.

Bhattacharya, N. (2001). Investors' trade size and trading responses around earnings announcements: An empirical investigations, The Accounting Review, 76(2), 221-244.

Bratten, B., Payne, J. and Thomas, W. (2013). Earning Management: Do Firms Play Follow the Leader?, working paper, 1-44.

Broadstock, D., Shu, Y. and Xu, B. (2011). Do Macroeconomic Conditions Affect Firm-level Earnings Forecasts?, International Journal of Trade, Economics and Finance, Vol. 2, No. 5, 450-454.

Bukit, R., Iskandar, T., (2009). Surplus Free Cash Flow, Earnings Management and Audit Committee, International Journal of Economics and Management, 3 (1), 204-223.

Burgstahler, D. and Dichev, I. (1997). Earnings Management to Avoid Earnings Decreases and Losses. Journal of Accounting and Economics 24, 99-126.

Burgstahler, D., Hail, L. and Leuz, C. (2006). The Importance of Reporting Incentives: Earnings Management in European Private and Public Firms. The Accounting Review, 81, 5, 983-1016.

Callao, S. and Jarne, J. (2011). The impact of the crisis on Earnings Management, Revista de Contabilidad-Spanish Accounting Review Vol. 14, 2, 59-85.

Callao, S., Jarne, J. and Wroblewski, D. (2014). The development of earnings management research. A review of literature from three different perspectives, Theoretical Journal of Accounting, issue: $79,135-177$.

Callao, S. Jarne, J. and Wroblewski, D. (2017). Why do companies from emerging countries manage earnings? Eurasian Journal of Business and Management, 5(2), 60-84.

Caramanis,C., Lennox,C., (2008). Audit effort and earnings management, Journal of Accounting and Economics, 45, 116-138. 
Chaney P. and Jeter, D. (1992). The effect of size on the magnitude of long-window earnings response coefficients, Contemporary Accounting Research, 8, 540-560.

Chen, C. (2010). Earnings Management, Earnings Manipulation: Evidence from Taiwanese Corporations, Providence University, working paper, 1-47.

Chen, A., Cheng, L., Cheng, K. and Chih, S. (2010). Earnings management, market discounts and the performance of private equity placements, Journal of Banking and Finance, 34, $1922-1932$.

Chen, X., Cheng, Q., Hao,Y., and Qiang,I. (2019). GDP Growth Incentives and Earnings Management: Evidence from China, SSRN papers, 1-24.

Chih, H., Shen, C. and Kang, F. (2007). Corporate Social Responsibility, Investor Protection, and Earnings Management: Some International Evidence, Journal of Business Ethics, 79, 179-198.

Chordia, T. and Shivakumar, L. (2002). Momentum, business cycle and time varying expected returns, Journal of Finance 57, 985-1019.

Cimini, R. (2015). How has the financial crisis affected earnings management? A European Study, Applied Economics, 47, 3, 302-317.

Clayton, G. and Giesbrecht, M. (1997). A guide to everyday economic statistics, New York: McGraw-Hill.

Cohen, D. and Zarowin, P. (2008). Economic Consequences of Real and Accrual-Based Earnings Management Activities, New York University, working paper, 1-43.

Conrad, J., Cornell, B. and Landsman, W. (2002). When is Bad News Really Bad News?, Journal of Finance 58: 2507-2532.

Datta, S., Iskandar-Datta, M. and Singh, V. (2013). Product market power, industry structure, and corporate earnings Management, Journal of Banking and Finance, 37, 3273-3285.

DeAngelo, L. (1986). Accounting numbers as market valuation substitutes: a study of management buyouts of public stockholders, The Accounting Review, 3, 400-420.

Dechow, P. and Dichev, I. (2002). The quality of accruals and earnings: The role of accrual estimation errors, The Accounting Review, 77 (Supplement), 35-59.

Dechow, P. and Sloan, R. (1991). Executive incentives and the horizon problem: An empirical investigation, Journal of Accounting and Economics, 14, 51-89.

Dechow, P., Richardson, S. and Tuna, A. (2002). Earnings management and costs to investors from firms meeting or slightly exceeding benchmarks, Unpublished Working Paper.

Dechow, P., Sloan, R. and Sweeney, A. (1995). Causes and Consequences of Earnings Manipulation: An Analysis of Firms Subject to Enforcement Actions by the SEC, Contemporary Accounting Research Vol.13, 1, 1-36.

Dhaliwal, D. (1988). The effect of the firm's business risk on the choice of accounting methods, The Journal of Business Finance and Accounting, 15, 289-302.

Dijmarescu, E. (2001). Globalization and Enlargement: What Future for Eastern Europe?, Eastern European Economics, vol. 39, no. 6, November-December, 6-22.

Dionisie, D. and Checchi, F. (2010). Corruption and Anti-Corruption Agencies in Eastern Europe and the CIS: a Practitioners' Experience, working paper, 1-17.

Dixit, A. (1989). Entry and exit decisions under uncertainty, Journal Politics Economics, 97, 620-638. 
Doukakis, L. 2014. The Effect of Mandatory IFRS Adoption on Real and Accrual-Based Earnings Management Activities, Journal of Accounting and Public Policy (JAPP), 33, 6, 551-572.

Dustmann, C., Glitz, A. and Vogel, T. (2009). Employment, wages, and the economic cycle: differences between immigrants and natives, IZA Discussion Papers, No. 4432 Provided in cooperation with: Forschungsinstitutzur Zukunft der Arbeit (IZA).

Eng, Li; Fang, H.; Tian, X.; Yu, T. and Zhang, H. (2019). Financial crisis and real earnings management in family firms: A comparison between China and the United States, Journal of International Financial Markets, Institutions and Money, Elsevier, 59, 184-201.

European Parliament and European Council. (2006). Directive 2006/43/EC of the European Parliament and of the Council of 17 May 2006 on statutory audits of annual accounts and consolidated accounts. Official Journal of the European Union (L 157):87-107.

Ewert, R. and Wagenhofer, A. (2005). Economic effects of tightening accounting standards to restrict earnings management, The Accounting Review, 80(4), 1101-1124.

Fama, E. (1980). Agency problems and the theory of the firm, Journal of Political Economy, 88, 288-307.

Fernandes da Silva, A.; Weffort, E., Flores, E., and Silva, G. (2014). Earnings management and economic crises in the Brazilian capital market. Revista de Administracao de Empresas, 54, 3, 268-283.

Filip, A. and Raffournier, B. (2011). The impact of the 2008-2009 Financial Crisis on earnings management: the European evidence, working paper.

Flores, E., Farah, E., Weffort, J., Fernandes da Silva, F, Nelson, L., and Carvalho, G. (2016). Earnings management and macroeconomic crises, Journal of Accounting in Emerging Economies, 6, 2, 179-202.

Foster, G. (1986). Financial Statement Analysis, Prentice-Hall, Englewood Cliffs, NJ.

Freeman, R. and Tse, S. (1992). An earnings prediction approach to examining intercompany information transfers, Journal of Accounting and Economics December, 509-523.

Gibbons, R. and Murphy, K. (1990). Relative performance evaluation for chief executive Officers, Industrial and Labor Relations Review February, 30-51.

Gorynia, M. (2005). Competitiveness of firms from ZiemiaLubuska and Poland's accession to the European Union, Journal for East European Management Studies, Vol. 10, Iss. 3, 195217.

Guan, L., Wright, C. and Leikam, S. (2005). Earnings Management and forced CEO dismissal, Advances in Accounting, 21, 61-81.

Habib, A., Bhuiyan, M. and Islam, A. (2012). Financial distress, earnings management and market pricing of accruals during the global financial crisis, Managerial Finance 39(2), 14 44.

Hasan, M. and Rahman, A. 2017. IFRS adoption and Earnings Management: a review and justification of Earnings Management model for developing countries, ELK Asia Pacific Journal of Finance and Risk Management, 8, 3, 2325-2349.

Hayes, J., Young, R., Matchett, M., Mccaffrey, M. and Cochran, C. (1992). Reading empirical research studies: The rhetoric of research, Hillsdale, NJ: Lawrence Erlbaum Associates.

Healy, P. (1985). The effects of bonus schemes on accounting decisions, Journal of Accounting and Economics, 7(1), 85-107. 
Healy, P. and Wahlen, J. (1999). A review of the Earnings Management literature and its implications for standards setting, Accounting Horizons, 13, 4, 365-383.

Hess, B. (2014). Three Essays on Audit Regulation, Audit Market Structure, and the Quality of Financial Statements, Dissertation zurErlangung des akademischen Grades Doktor der Wirtschaftswissenschaften am FachbereichWirtschaftswissenschaften der Universität Konstanz, 1-224.

Higson, C., Holly, S. and Kattuman, P. (2002). The cross-sectional dynamics of the US business cycle, Journal of Economic Dynamics and Control, 26, 1539 - 1555.

Hinkle, D., Wiersma, W. and Jurs, S. (1988). Applied statistics for the behavioral sciences, Boston: Houghton.

Holthausen, R., Larcker, D. and Sloan, R. (1995). Annual bonus schemes and the manipulation of earnings, Journal of Accounting and Economics 19, 29-74.

Hung, M. and Subramanyam, K. (2007). Financial statement effects of adopting international accounting standards: The case of Germany, Review of Accounting Studies, 12(4), 21-48.

Jaruga, A. and Ho, S. (2002). Management accounting in transitional economies, Management Accounting Research, 13, 375-378

Jensen, M. (2004). The Agency Costs of Overvalued Equity and the Current State of Corporate Finance, European Financial Management, Vol. 10, No. 4, 549-565.

Jiang, J., Fan, J. and Fan, J. (2010). Estimation in additive models with highly or non highly correlated covariates, The Annals of Statistics, 38, 3, 1403-1432.

Jin, Q. (2005). Business Cycle, Accounting Behaviour and Earnings management, 1-34.

Johnson, N. (1999). The year of the Accountant, http://www.sec.gov/

Jones, J. (1991). Earnings Management during Import Relief Investigations, Journal of Accounting Research, 29,(2), 193-228.

Kang, S. and Sivaramakrishnan, K. (1995). Issues in testing earnings management and an instrumental variable approach, Journal of Accounting Research, 353-367.

Kasznik, R. (1999). On the association between voluntary disclosure and earnings management, Journal of Accounting Research, 37, 57-81.

Kempen, R. (2010). Earnings management in public and private companies in The Netherlands, Master thesis Accounting and Finance, Erasmus University Rotterdam, 1-32.

Kersten, M. 2011. Earnings Management in Private Companies: A Comparison Between IFRS and UK GAAP, Master Thesis Department Accountancy, Tilburg School of Economics and Management, Tilburg University, 1-49.

Key, K. (1997). Political cost incentives for earnings management in the cable television industry, Journal of Accounting and Economics, 23, 309-337.

Khurana, I., Martin, X., Pereira, R. and Raman, K. (2006). Economic state-varying incetives and timely recognition of economic losses working paper, University of Missouri Columbia.

Kim, J., Yi, C., (2005). Ownership Structure, Business Group Affiliation, Listing Status,and Earnings Management: Evidence from Korea, Hong Kong Polytechnic University, paper work, $1-57$.

Kiyotaki, N. and Moore, J. (1997). Credit Cycles, The Journal of Political Economy, Vol. 105, No. 2, 211-248. 
Klein, A. and Marquardt, C. (2006). Fundamentals of Accounting Losses, The Accounting Review: January, Vol. 81, No. 1, 179-206.

Koh, P. (2003). On the association between institutional ownership and aggressive corporate earnings management in Australia, The British Accounting Review, 35, 105.

Köke, J. and Schroder, M. (2006). The Prospects of Capital Markets in Central and Eastern Europe, Discussion Paper No. 02-57, 1-32.

KosmalaMacLullich, K. and Gurau, C. (2004). The relationship between economic performance and accounting system reform in the CEE region: The cases of Poland and Romania, Centre for Economic Reform and Transformation Discussion Paper 2004/06.

Kothari, S. (2001). Capital markets research in accounting. Journal of Accounting and Economics, 31, 105-231.

Kothari, S., Leone, A. and Wasley, C. (2005). Performance matched discretionary accrual measures, Journal of Accounting and Economics, 39, 163-197.

Lambrecht, B. and Myers, S. (2007). A Theory of Takeovers and Disinvestment, Journal of Finance, 62(2), 809-845.

Larcker, D. and Richardson, S. (2004). Fees paid to audit firms, accruals choices, and corporate governance, Journal of Accounting Research, 42 (3), 625-658.

Lee, J. (2007). Earnings management to just meet Analysts' forecast, working paper, 1-42.

Lee, R., Lee, S. and Mason, A. (2006). Charting the Economic Life Cycle, Nber working paper series.

Lee, C. and Xue, S. (2004). Earnings Management of Loss-Firms in China, Tulane University and Tsinghua University, working paper, 1-31.

Leuz, C., Nanda, D. and Wysocki, D. (2003). Earnings management and investor protection: An international comparison, Journal of Financial Economics, 69, 505-527.

Lim, C., Ding, D. and Thong, T. (2008). Firm diversification and earnings management: evidence from seasoned equity offerings, Review of Quantitative Finance and Accounting, 30, $1,69-92$.

Lin, K. (2006). The impact of tax holidays on earnings management: An empirical study of corporate reporting behavior in a developing-economy framework, The International Journal of Accounting, 41, 163-175.

Lin, S., Lin, T., and Tsai, Y. (2004). Earnings Management in Taiwan's Imputation Tax System, Taiwan Accounting Review, 4, 2, 1-22.

Liu, C. and Ziebart, D. (1999). Anomalous Security Price Behavior Following Management Earnings Forecasts. Journal of Empirical Finance, 6, 405-429.

Liu, Q. and Lu, Z. (2004). Earnings Management To Tunnel: Evidence from China's Listed Companies, working paper, 1-31.

Louis, H. (2004). Earnings management and the market performance of acquiring firms, Journal of Financial Economics, vol. 74, 121-48.

Matis, D., et al. (2010). Jones, Dechow and Kasznik models significance in the Romanian economic environment, Annales Universitatis Apulensis Series Oeconomica, 12, 1, 1-14.

Mittal, A. and Ajay, G. (2019). How do Indian firms cope with a crisis? Earnings management characteristics of CNX Nifty 100 companies, Indian Institute of Management, Lucknow, 1-32. 
Moravcsik, A. (1998). The Choice for Europe: Social Purpose and State Power from Messina to Maastricht, London: UCL Press.

MSCI Inc. Annual Reports (2012). http://ir.msci.com/

Ohn, J., Taylor, L. and Pagan, A. (2004). Testing for duration dependence in economic cycles Econometrics Journal, volume 7, 528-549.

Othman, H. and Zeghal, D. (2006). A study of earnings-management motives in the AngloAmerican and Euro-Continental accounting models: The Canadian and French cases, The International Journal of Accounting, 41, 406-435.

Paiva, I. and Costa, I. (2013). The effect of size on the level of earnings management in family firms, working paper, 1-42.

Palepu, K., Healy, P., Bernard, V., Wright, S. and Lee, P. (2004). Business analysis and valuation: using financial statements, 3. ed. Thomson Learning: USA.

Park, M. and Ro, B. (2004). The effect of firm-industry earnings correlation and announcement timing on firms' accrual decisions, The British Accounting Review, 36, 269-289.

Porter, M. and McGahan, A. (1997). How much does industry matter, really? Strategic Management Journal, 18, 15-30.

Pozzoli, M. and Parthenope, F. (2018). Earnings management in developing countries. The case of Brazilian real estate industry. Academy of Accounting and Financial Studies Journal, 22, 1, 1-12.

Prochazka, D. (2017). Specifics of IRS adoption by Central and Eastern European countries: evidence from research. Scientific Annals of Economics and Busines, 64, 1, 59-81.

Pyo, Y. and Lustgarten, S. (1990). Differential intra-industry information transfer associated with management earnings forecasts, Journal of Accounting and Economics December, 365-379.

Rajgopal, S., Shivakumar, L. and Simpson, A. (2007). A Catering Theory of Earnings Management, working paper, 1-57.

Rangan, S. (1998). Earnings management and the underperformance of seasoned equity offerings, Journal of Financial Economics 50, 101-122.

Razzaque, R., Rahman, M., and Salat, A. (2006). Earnings Management: an analysis on textile sector of Bangladesh, The Cost and Management, 34, 5, 5-13.

Richardson, V. (2000). Review of Quantitative Finance and Accounting, Information Asymmetry and Earnings Management: Some Evidence, 15, issue 4, 325-347.

Robson, M. (1996). Macroeconomic Factors in the Birth and Death of U.K. Firms: Evidence from Quarterly VAT Registration, Manchester School, 64 (2), June, 57-69.

Rudra, T. and Bhattacharjee, D. (2012). Does IFRs Influence Earnings Management? Evidence from India, Journal of Management Research, Vol. 4, No. 1, 1-13.

Saleh, N., Iskandar, T., Rahmat, M., (2005). Earnings Management and Board Characteristics: Evidence from Malaysia, JurnalPengurusan, 24, 77-103.

Shackelford, D. and Shevlin, T. (2001). Empirical research in accounting, Journal of Accounting and Economics, 31, 321-387.

Shen, C. and Chih, H. (2005). Investor protection, prospect theory, and earnings management: An international comparison of the banking industry, Journal of Banking and Finance, 29, 2675-2697. 
Shivakumar, L. (1996). Estimating abnormal accruals for detection of earnings management, working paper, Vanderbilt University, March.

Skarda, K. (2010). Public vs. Private company valuations: What's the difference?, White Paper, Alied Business Group, 1-2.

Stevens, J. (1986). Applied multivariate statistics for the social sciences, Hillsdale, NJ: Lawrence Erlbaum Associates.

Sucher, P. and Jindrichovska, I. (2004). Implementing IFRS: A Case Study of the Czech Republic. Accounting in Europe, Vol. I, 109- 142.

Sundgren, S. (2007). Earnings Management in Public and Private companies - evidence from Finland, LTA, 1, 1-29.

Sundvik, D. (2017). A review of earnings management in private firms in response to tax rate changes, Nordic Tax Journal, 1:151-161.

Swiderski, M. (2010). Earnings management in Central and Eastern Europe: the Czech, Hungarian and Polish cases. Dissertation thesis, University of Amsterdam, 1-66.

Tanzi, V. (1999). Transition and the changing role of government, Finance Dev. 36 2, 20-23.

Teoh, S., Welch, I. and Wong, T. (1998). Earnings management and the underperformance of seasoned equity offerings, Journal of Financial Economics, 50, 63-99.

Terreberry, S. (1968). The evolution of organizational environments, Administrative Science Quarterly, 12, 4, 590-613.

Thompson, J. (1967). Organizations in action, New York, NY. McGraw-Hill.

Tylsch, R. (2009). Real economic activity and earnings management from a cross-country perspective, Erasmus School of Economics, 65-82.

Vander Bauwhede, H. and Willekens, M. (2003). Earnings Management in Belgium: a review of the empirical evidence, TijdschriftvoorEconomieen Management, 48, 2, 199-217.

Vellam, I. (2004). Implementation of International Accounting Standards in Poland: Can true convergence be achieved in practice?, Accounting in Europe, 1, 143-167.

Veronesi, P. (1999). Stock Market Overreactions to Bad News in Good Times: A Rational Expectations Equilibrium Model, The Review of Financial Studies, Winter, 12, 5, 975-1007.

Verrecchia, R. (1983). Discretionary disclosure, Journal of Accounting and Economics, 5, 179-194.

Visegrad Group, http://www.visegradgroup.eu/

Watts, R. and Zimmerman, J. (1986). Positive accounting theory, Englewood Cliffs, New Jersey: Prentice Hall.

Watts, R. and Zimmerman, J. (1990). Positive accounting theory: a ten year perspective, The Accounting Review 65 (1), 131-156.

Yoon, S. and Miller, G. (2002). Earnings management of seasoned equity offering firms in Korea, The International Journal of Accounting, 37, 57-78.

Young, S. (1999). Systematic measurement error in the estimation of discretionary accruals: an evaluation of alternative modelling procedures, Journal of Business, Finance and Accounting, 26, 833-862.

Yu, Q., Du, B., Sun, Q., (2006). Earnings management at rights issues thresholds-Evidence from China. Journal of Banking \& Finance, 30, 3453-3468. 
Annex 1: Results on Normality test of our four samples (absolute values of discretionary accruals)

\begin{tabular}{|c|c|c|c|c|c|c|c|}
\hline \multicolumn{8}{|c|}{ Tests of Normality } \\
\hline & \multirow[b]{2}{*}{ Country } & \multicolumn{3}{|c|}{ Kolmogorov-Smirnov ${ }^{a}$} & \multicolumn{3}{|c|}{ Shapiro-Wilk } \\
\hline & & Statistic & $\mathrm{df}$ & Sig. & Statistic & $\mathrm{df}$ & Sig. \\
\hline \multirow[t]{4}{*}{$\mathrm{DA}$} & Czech R. & .210 & 14,343 & .000 & - & - & - \\
\hline & Hungary & .224 & 15,757 & .000 & - & - & - \\
\hline & Poland & .244 & 798 & .000 & .488 & 798 & .000 \\
\hline & Slovakia & .142 & 1,491 & .000 & .788 & 1,491 & .000 \\
\hline
\end{tabular}

Annex 2: Industries classification based on the first digit of the Standard Industry Code (SIC-code), and the percentage of the distribution of the companies in each industry

\begin{tabular}{|l|c|c|c|c|c|c|c|c|c|c|c|}
\hline & \multicolumn{10}{|c|}{ INDUSTRY } & \multirow{2}{*}{ TOTAL } \\
\cline { 2 - 11 } & 0 & 1 & 2 & 3 & 4 & 5 & 6 & 7 & 8 & 9 & \\
\hline Czech R. & $6.5 \%$ & $9.7 \%$ & $29.1 \%$ & $7.5 \%$ & $30.8 \%$ & $2.4 \%$ & $5.3 \%$ & $4.5 \%$ & $3.3 \%$ & $0.7 \%$ & $100 \%$ \\
\hline Poland & $2.2 \%$ & $10.3 \%$ & $16.9 \%$ & $9.4 \%$ & $35.4 \%$ & $2.4 \%$ & $8.0 \%$ & $3.1 \%$ & $11.5 \%$ & $0.8 \%$ & $100 \%$ \\
\hline Hungary & $0.9 \%$ & $9.6 \%$ & $27.2 \%$ & $4.4 \%$ & $43.9 \%$ & $4.4 \%$ & $2.6 \%$ & $1.8 \%$ & $4.4 \%$ & $0.9 \%$ & $100 \%$ \\
\hline Slovakia & $5.2 \%$ & $20.2 \%$ & $24.9 \%$ & $8.0 \%$ & $32.9 \%$ & $3.3 \%$ & $0.9 \%$ & $1.4 \%$ & $2.3 \%$ & $0.9 \%$ & $100 \%$ \\
\hline TOTAL & $4.2 \%$ & $10.5 \%$ & $22.9 \%$ & $8.4 \%$ & $33.5 \%$ & $2.5 \%$ & $6.3 \%$ & $3.6 \%$ & $7.2 \%$ & $0.8 \%$ & $100 \%$ \\
\hline
\end{tabular}

According to SIC-code:

1 - agriculture, forestry and fishing industries, 2 - manufacturing, mining and quarrying and other industry, 3 - construction, 4 - wholesale and retail trade, transportation and storage, accommodation and food service activities,5 - information and communication industry, 6 financial and insurance activities, 7 - real estate activities,8 - professional, scientific, technical, administration and support service activities, 9 - public administration, defence, education, human health and social work activities, 0 - other services (group "other" comprises establishments engaged in providing services not specifically in previous category of public services, for example, Hunting, trapping and related service activities; Marine services). 
Annex 3: Panel A: Statistics on discretionary accruals over the years

\begin{tabular}{|c|c|c|c|c|c|c|c|}
\hline & 2003 & 2004 & 2005 & 2006 & 2007 & 2008 & 2009 \\
\hline \multicolumn{8}{|c|}{ Panel A: the Czech Republic sample } \\
\hline Mean & -0.0318 & -0.0210 & -0.0279 & -0.0043 & -0.0059 & -0.0388 & -0.0580 \\
\hline Standard deviation & 0.1478 & 0.1599 & 0.1409 & 0.1389 & 0.1663 & 0.1348 & 0.1220 \\
\hline Median & -0.0422 & -0.0310 & -0.0401 & -0.0206 & -0.0200 & -0.0464 & -0.0587 \\
\hline \multicolumn{8}{|c|}{ Panel B: Polish sample } \\
\hline Mean & -0.0323 & -0.0059 & -0.0325 & -0.0248 & -0.0190 & -0.0470 & -0.0544 \\
\hline Standard deviation & 0.1799 & 0.1625 & 0.1531 & 0.1760 & 0.1427 & 0.1404 & 0.1143 \\
\hline Median & -0.0380 & -0.0221 & -0.0399 & -0.0362 & -0.0316 & -0.0461 & -0.0529 \\
\hline \multicolumn{8}{|c|}{ Panel C: Hungarian sample } \\
\hline Mean & 0.0470 & -0.0242 & -0.0259 & 0.0201 & -0.0315 & -0.0567 & -0.0564 \\
\hline Standard deviation & 0.3247 & 0.1783 & 0.1158 & 0.1905 & 0.1054 & 0.1143 & 0.1020 \\
\hline Median & -0.0244 & -0.0495 & -0.0444 & -0.0159 & -0.0348 & -0.0486 & -0.0558 \\
\hline \multicolumn{8}{|c|}{ Panel D: Slovakian sample } \\
\hline Mean & -0.0478 & -0.0069 & -0.0494 & -0.0294 & -0.0618 & -0.0551 & -0.0972 \\
\hline Standard deviation & 0.1098 & 0.1113 & 0.0841 & 0.1233 & 0.1643 & 0.1477 & 0.1058 \\
\hline Median & -0.0508 & -0.0286 & -0.0480 & -0.0424 & -0.0708 & -0.0608 & -0.0969 \\
\hline
\end{tabular}




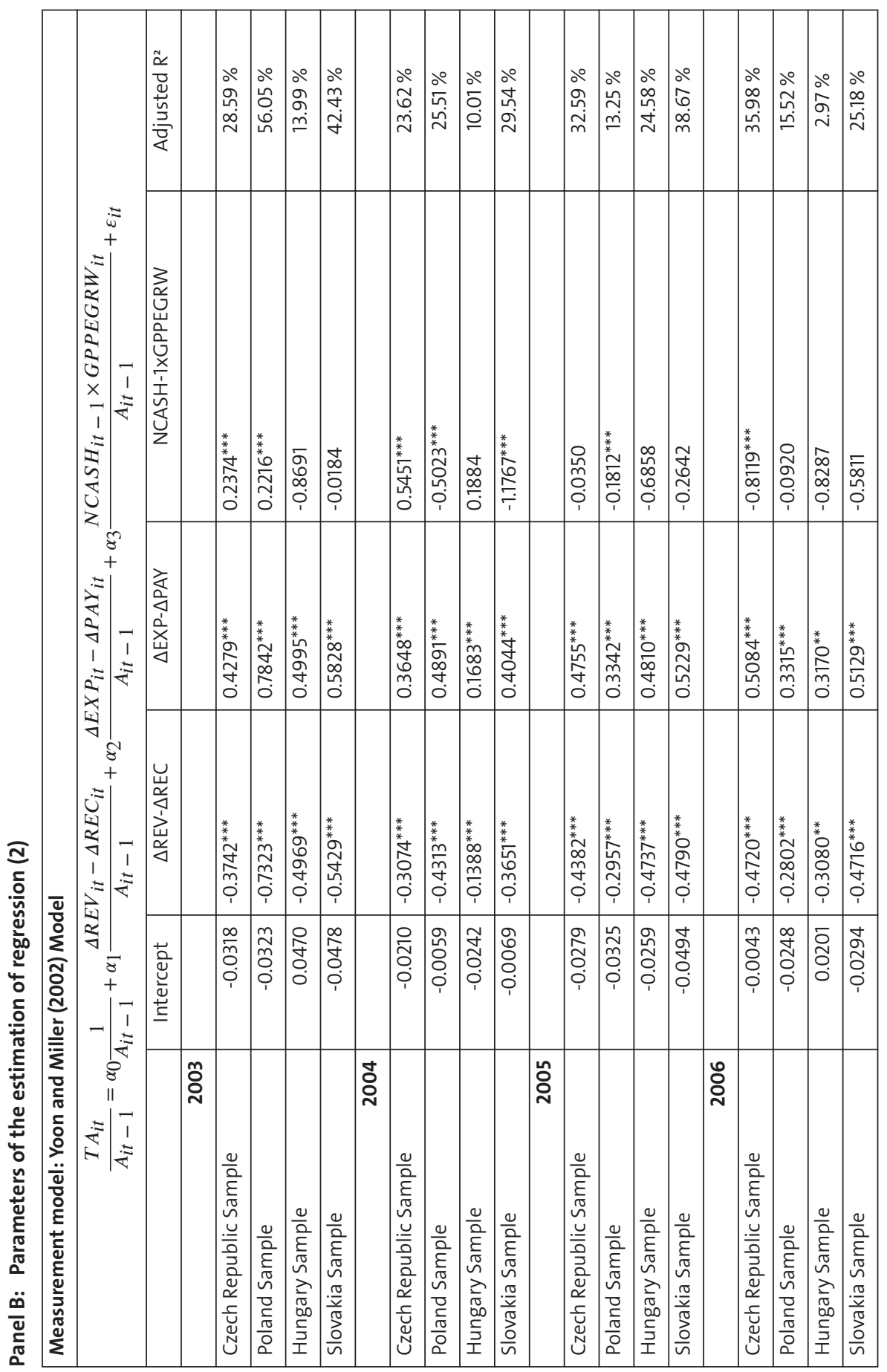




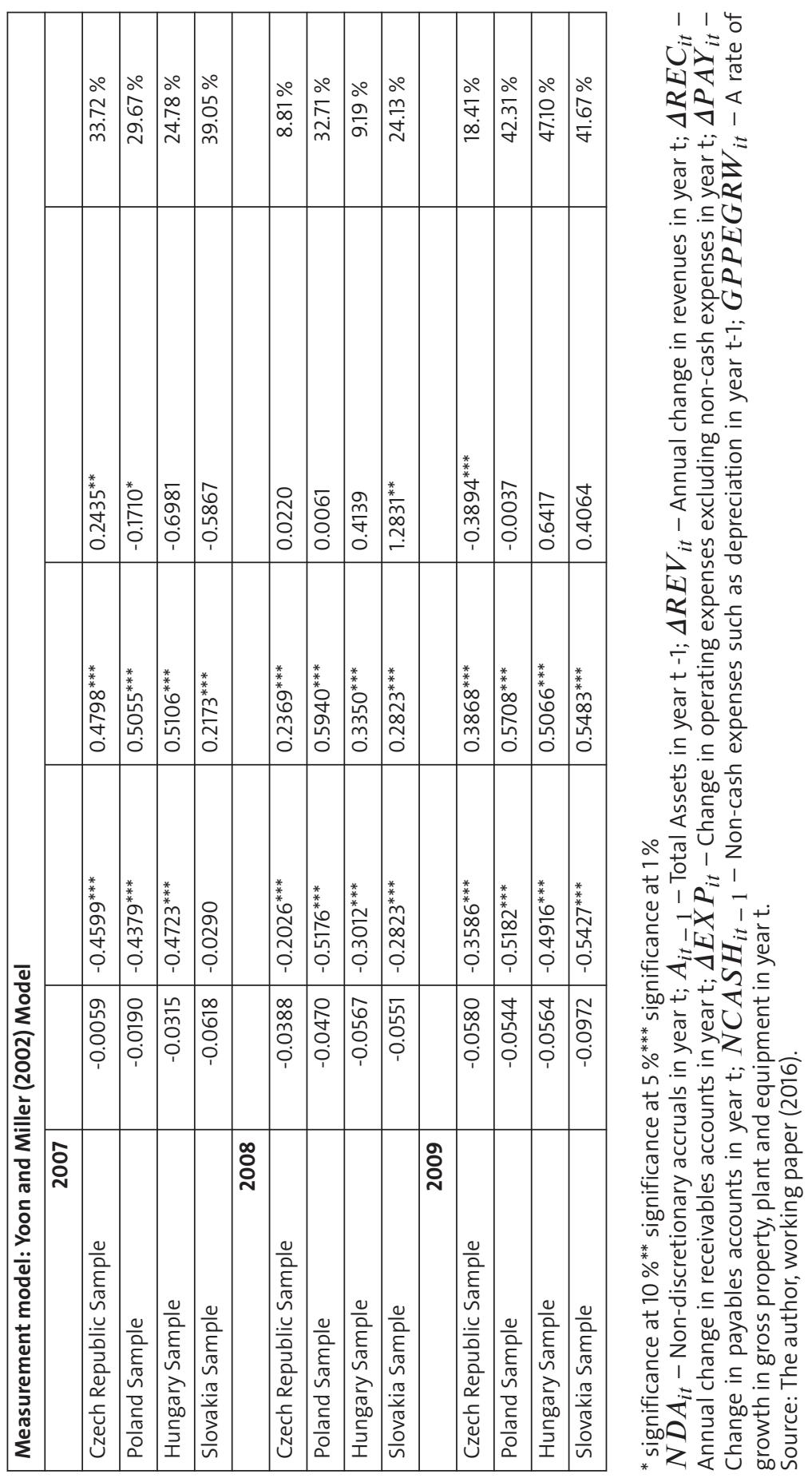

